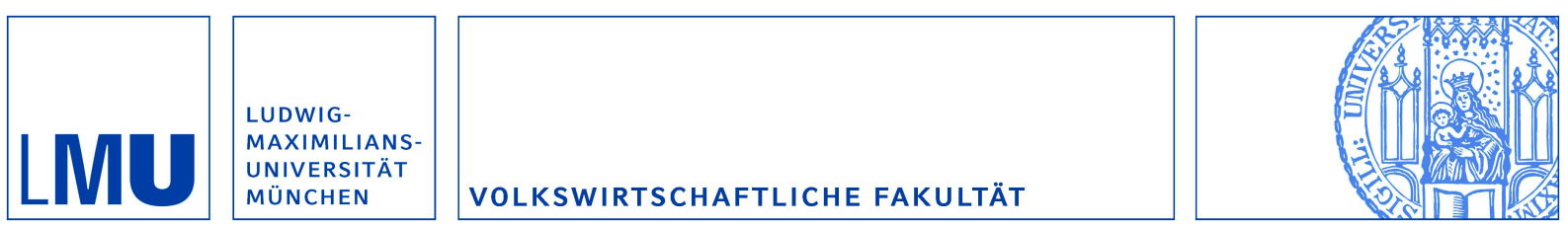

Andreoli-Versbach, Patrick und Franck, Jens-Uwe:

Endogenous Price Commitment, Sticky and Leadership Pricing: Evidence from the Italian Petrol Market

Munich Discussion Paper No. 2013-9

Department of Economics

University of Munich

Volkswirtschaftliche Fakultät

Ludwig-Maximilians-Universität München

Online at https://doi.org/10.5282/ubm/epub. 16182 


\title{
Endogenous Price Commitment, Sticky and Leadership Pricing: Evidence from the Italian Petrol Market
}

\author{
Patrick Andreoli-Versbach ${ }^{*}$ and Jens-Uwe Franck ${ }^{\dagger \neq}$
}

July 2013

\begin{abstract}
This article studies dynamic pricing strategies in the Italian gasoline market before and after the market leader unilaterally announced its commitment to adopt a sticky-pricing policy. Using daily Italian firm level prices and weekly average EU prices, we show that the effect of the new policy was twofold. First, it facilitated price alignment and coordination on price changes. After the policy change, the observed pricing pattern shifted from cost-based to sticky-leadership pricing. Second, using a dif-in-dif estimation and a synthetic control group, we show that the causal effect of the new policy was to significantly increase prices through sticky-leadership pricing. Our paper highlights the importance of price-commitment by a large firm in order to sustain (tacit) collusion.
\end{abstract}

Keywords: tacit collusion, leadership pricing, sticky pricing, endogenous commitment

JEL classification: K21, K42, L13, L41, L71

\footnotetext{
* First and contact author; International Max Planck Research School for Competition and Innovation, Munich Center for Innovation and Entrepreneurship Research and Ludwig-Maximilians-Universität München. Address: Marstallplatz 1, 80539 Munich, Germany, Phone: +49 (0)160 3081 775, Fax: +49 (0)89 24246 503, Email: patrick.andreoli-versbach@imprsci.ip.mpg.de.

† Ludwig-Maximilians-Universität München, Ludwigstrasse 29/III, 80539 Munich, Germany, Phone: +49 (0)89 21802905 , Fax: +49 (0)89 2180 2904, Email: jens-uwe.franck@jura.uni-muenchen.de.

¥We thank David Abrams, Rosa Abrantes-Metz, Carlo Bardini, Tomaso Duso, Fabio Massimo Esposito, Valentina Giuliani, Andrea Güster, Dietmar Harhoff, Justus Haucap, Francesco Manarese, Michael Meurer, Hans Müller, Alessandro Noce, Martin Pesendorfer, Fabio Pinna, Stephen Ryan, Pierluigi Sabbatini, Monika Schnitzer, Simcoe Timothy, John Sutton and Joachim Winter. Thanks for insightful comments and suggestions are due to participants at the Mannheim Law \& Economics Forum (2013), the EALE Conference in Stockholm (2012), the LawEcon Workshop at the University of Bonn and the Max Planck Institute for Research on Collective Goods (2012), the EARIE in Rome (2012), the EDGE conference in Bocconi (2011), the CISS workshop in Turkey (2011), the Max Planck Institute conference in Wildbad Kreuth (2011), the ZEW conference on "Quantitative assessment of Antitrust Analysis" in Mannheim (2010), and PhD workshops at the Ludwig-MaximiliansUniversität München. We have also benefited from discussions with and comments from practitioners at three economic consulting firms in London and Oxford: Compass Lexecon, NERA and Oxera. Finally, we are indebted to seminar participants at the Italian Antitrust Authority, the Italian Central Bank and the German Federal Cartel Office for their valuable suggestions. Patrick Andreoli-Versbach gratefully acknowledges financial support from the Deutsche Forschungsgemeinschaft through GRK 801 and the generous financial support from the International Max Planck Research School for Competition and Innovation. All data and codes from this paper will be available online for the purpose of replication or further research as soon as the paper is accepted for publication.
} 


\section{Introduction}

Understanding the interdependence of pricing strategies in oligopolies is a fundamental issue. Firms with market power might use a specific pricing behavior to influence competitors' actions in order to facilitate price coordination and sustain (tacit) collusion. ${ }^{1}$

In this paper we provide empirical evidence of the role of unilateral price commitment to sustain (tacit) collusion and highlight the role of price-stickiness as an endogenous commitment device to collude. Infrequent and large price changes by the market leader may facilitate tacit coordination on the leader's focal price and result in higher prices. On $6^{\text {th }}$ October 2004, ENI, the market leader on the Italian petrol market, publicly announced a new pricing policy which consisted of infrequent price variations (sticky pricing) and price changes larger in magnitude. ENI increased the time lag between price changes from 6 to 16 days and increased the mean price change from $1 \%$ to $5.8 \%$. About five months later the Italian Truckers' Association complained to the Italian antitrust authority about collusion by the Italian petrol firms. Allegedly, firms maintained high and aligned prices which they changed simultaneously. ${ }^{2}$ Because the antitrust authority had no evidence of firms' explicit communication, it ended its investigation without issuing a formal decision after the firms accepted to restrict pricing transparency. ${ }^{3}$

In the empirical analysis we document that the leader's unilateral sticky price commitment with larger price changes had two major effects: first, it facilitated price alignment and coordination on the leader's focal price with the observed pricing pattern shifting from cost-based to stickyleadership pricing. Second, prices increased relatively to a control group. To our knowledge this is the first paper that empirically shows the role of endogenous price commitment by the market leader who acted both as the initiator of the new collusive pricing and as the coordinator of price changes.

Our research is related to two strands of literature: cartel detection and dynamic pricing. Economists have long used their knowledge of collusive behavior to derive testable hypotheses to distinguish between collusion and competition. ${ }^{4}$ Porter and Zona (1999) use data from the

\footnotetext{
${ }^{1}$ While firms might also (illegally) communicate to collude, the benefits of communication might be smaller for oligopolies. In a meta-study of detected cartels Levenstein and Suslow (2006) show that there is no clear relation between the likelihood of collusion and concentration. Using a laboratory experiment Fonseca and Norman (2012) find that concentrated industries are able to collude irrespectively of communication. Thus, understanding the role of specific pricing strategies used to tacitly collude is of key importance for competition policy and regulators as evidence of collusion is mostly based on evidence of communication.

2 Autorità Garante della Concorrenza e del Mercato, 18.1.2007, Case I681 - Prezzi dei carburanti in rete, Provvedimento no. 16370 , Section I para. 1; available at http://www.agcm.it.

3 The inability of antitrust authorities to deal with tacit collusion poses the question on whether and how antitrust policy should respond to tacit collusion in oligopolies, an issue we discuss in Andreoli-Versbach and Franck (2013). For the final report by the Italian antitrust authority on this case see: Autorità Garante della Concorrenza e del Mercato, 20.12.2007, Case I681 - Prezzi dei carburanti in rete, Provvedimento no. 17754; available at http://www.agcm.it.

${ }^{4}$ See Harrington (2008) for a review of empirical cartel detection and Zitzewitz (2012) for a general review of forensic economics.
} 
Ohio school milk auction and find that bids by colluding firms decreased the further the distance from the schools which is inconsistent with a competitive model. Abrantes-Metz et al. (2006) analyze structural breaks in the pricing of firms supplying seafood in a bid-rigging conspiracy. They find that the price mean (variance) significantly decreased by $16 \%$ (increased by $200 \%$ ) after the collapse of the cartel. While these studies use data on detected cartels, other papers build test hypotheses to uncover cases of collusion. Knittel and Stango (2003) use data from the credit card market during the 1980s and find that a non-binding price ceiling may serve as a focal point to facilitate tacit collusion. Duso et al. (2012) test whether upstream R\&D cooperation leads to downstream collusion and find that large horizontal networks are most likely to collude. Finally, Christie and Schultz (1994) have documented "suspicious" bid-ask quotes by market makers in the Nasdaq who increased their margins by avoiding the use of "odd-eights". 5

The second strand of literature related to our study examines dynamic pricing strategies in gasoline markets. A large part of this literature has focused on asymmetric price-cost adjustment (Borenstein et al., 1997, Bachmeier and Griffin, 2003, Tappata, 2009). Most papers find that prices respond faster to cost increases than to cost decreases, a phenomenon referred to as "rockets and feathers". This asymmetry has been related to inventories, collusion, and consumers' searching costs. More related to this article is a series of empirical papers aiming at characterizing the properties of Maskin and Tirole (1988) Edgeworth cycles observed in gasoline markets in the U.S. (Lewis, 2012, Eckert, 2003), Canada (Noel, 2007) and Australia (Wang, 2009). Noel (2007) analyzes dynamic pricing in 19 Canadian cities over 574 weeks. Using a Markowswitching regression he estimates both the prevalence and structural characteristics of the three pricing patterns he finds: cost-based pricing, sticky-pricing and price cycles. He finds that cycles (sticky-pricing) are more prevalent when there are many (few) small firms. Wang (2009) studies the Australian gasoline market in relation to a unique policy change which required firms to change their prices simultaneously and only once per day. This policy increased the "commitment costs" by firms to be the first to "relent" after prices fell in a cycle. Whereas before the law a single large firm appeared to be the price leader and was consistently the first to raise prices, after the policy change firms adopted mixed strategies and took turns at being the first to raise prices. Lewis (2012) studies the role of price leadership in coordinating price increases in cycling gasoline markets in the U.S. and finds that the first price increases tend to stem from retail chains that operate a large number of stations.

\footnotetext{
5 They found relevant evidence of collusion between brokerage firms making markets in Nasdaq stocks by looking at the bid-ask spread, the traders' margin. As soon as their results became public, this pricing behaviour ended and the subsequent investigation by the Securities and Exchange Commission led to settlements of over $\$ 1$ billion.
} 
Our paper complements the literature in three important ways. First, we document the role of endogenous price commitment in switching from cost-based to sticky-focal pricing equilibrium. Second, while Wang (2009) and Lewis (2012) highlight the importance of leadership pricing in the relenting phase of Edgeworth cycles we show its importance in coordinating price changes in response to cost shocks during sticky-pricing. Finally, our setting with a clear shift in the industry's pricing behaviour allows us to develop an identification strategy that quantifies the causal effect of sticky-focal pricing on the price level. This enables us to draw some conclusions on the pro-collusive effects of sticky-focal pricing as compared to cost-based pricing.

The key difficulty in analyzing dynamic pricing strategies is the non-experimental nature of the data. Neither the new pricing policy by the market leader, ENI, nor the leader's (large) price changes which were matched by those of its competitors can be regarded as exogenous. In addition demand and firm-level cost shocks are unobservable. Using existing theoretical and empirical models on price leadership (Rotemberg and Saloner, 1990, and Mouraviev and Rey, 2011) and price stickiness (Athey and Bagwell, 2001, 2008, Athey et al., 2004, Abrantes-Metz et al., 2006, Blanckenburg et al., 2012, and Connor, 2005) we first characterize and then evaluate the effects of the different pricing patterns. First, we use daily firm-level wholesale prices in Italy to characterize the effect of the leader's sticky price commitment on the price interdependence within the Italian gasoline market. Second, using the weekly average wholesale prices of eight other European countries we test whether the sticky-leadership equilibrium led to a price increase.

In the first part of our analysis we compare the interdependence of the leader's and competitors' price changes before and after the market leader introduced its new pricing policy. Before the policy change, competitors adjusted prices every five days following short run cost changes, but after the policy change the time lag between their price changes increased to nine days and the price-cost correlation decreased from .89 to .73 . Using a logit model with firms' fixed effect we show that the probability of a competitor aligning its price to the leader's in response to a leader's price change significantly increased after the policy change. In addition, as price alignment is defined narrowly (up to the third decimal) we also look at the percentage price difference between the leader and its competitors. Results are consistent across specifications and point out that competitors coordinated price changes following the leader's focal price after, but not before the new policy.

In the second part we show that sticky-leadership pricing had a positive and significant effect on prices. We use a difference-in-differences approach to compare Italian prices with European prices before and after the implementation of the policy. In addition, as researchers often select 
comparison groups on the basis of subjective measures of similarity between treated and untreated units, we employ a synthetic control group estimation as developed by Abadie and Gardeazabal (2003) and Abadie, Diamond, and Hainmueller (2010) to demonstrate that the choice of selected control groups does not drive our results. The synthetic control group is constructed using a data-driven weight of European prices that minimizes the pre-treatment differences between the Italian price and the resulting synthetic control group. This lowers the discretion of researchers in selecting control groups and forces them to show the relative weight of each individual control group.

Our results are consistent across specifications and show that Italian prices significantly increased when compared to a control group after the new sticky-leadership pricing was in place.

The paper proceeds as follows: in section 2 we describe the main features of the Italian petrol market and in section 3 we present the data. In section 4 we perform the empirical analysis and section 5 is a conclusion.

\section{The Italian Petrol Industry}

The Italian wholesale gasoline industry is characterized by many traits which facilitate collusion: a small number of vertically integrated firms, high entry costs, inelastic demand, frequent and small purchases by different consumers and a transparent cost and price structure. ${ }^{6}$ There are nine firms operating in the market holding $95 \%$ of market share, while the rest is held by small independent retailers that purchase gasoline from one of the vertically integrated firms. The nine big players are ENI, ${ }^{7}$ Esso, ERG, Shell, Q8, Total, API/IP ${ }^{8}$, and Tamoil.

Market shares are asymmetric across firms. In 2004 ENI, the market leader, accounted for about $35 \%$ market share. The second largest player on the market was Esso with a market share of 16\%, followed by Q8 with around 11\%. The six other firms account for a market share that ranges between $5 \%$ and $8 \%$. All firms are vertically integrated, i.e. they either have access to crude oil or they hold shares in companies that run refineries in Italy or Europe. Each firm operates a retailer network with exclusive contracts binding the retailers to the wholesaler on a long-term basis which makes it difficult for other companies to enter the market or to increase their market share. The retailers, petrol stations, can either be independent companies or are directly owned by the wholesalers. Half of these stations are owned by the oil companies, the

\footnotetext{
${ }^{6}$ See Levenstein and Suslow (2006) for a discussion on the determinants of cartels' success.

${ }^{7}$ ENI acts on the Italian market under the name of "Agip", its "Refining and Marketing” division dealing with gasoline.

8 API and IP merged in 2005, when ENI sold IP to API.
} 
other half are owned by small private companies, each of them managing on average 30 to 50 stations in one city or region.

Distribution and price setting works as follows: the oil companies communicate to the manager of the petrol station the so-called "suggested price", the price we observe in our data. This price is a non-binding indication of the final retail price petrol stations supplied by that company should charge to consumers. The final retail price of petrol stations with the same brand might vary slightly from region to region due to different fiscal regimes, storage and transportation costs. The owners of the petrol station receive a discount on the suggested price depending on the incentive contract they have negotiated with their respective wholesaler, and the owners are allowed to charge up to a certain percentage on top of the suggested price. Thus, the retail price varies between a minimum, the suggested price minus the discount, and a maximum that is fixed by the wholesaler, so even though the station managers fix the final retail price, their available range falls between their purchase price and the maximum price they are allowed to charge, as stipulated by the oil company. Thus, their freedom to set prices is low and the effect of managerial choice of petrol station owners does not bias this analysis which focuses on competition between the nine large wholesalers and not between the owners of petrol stations. The strong similarity between "suggested" and final prices has been confirmed by the Italian antitrust authority which stated that "the suggested price constitutes an extremely narrow measure in relation to what the consumer will pay for retail gasoline."9

With respect to the cost structure, the most important cost for oil companies is the Premium Unleaded Gasoline Mediterranean Price, which is reported by the Platts. ${ }^{10}$ In Italy the reference cost for buying gasoline on the refinery markets based in Genoa (north-west Italy) and Lavera (southern France) is the Platts Cif Med (Platts). This price index is widely regarded as the major (opportunity) cost for wholesalers ${ }^{11}$ and is used by market-specific newspapers and industry insiders to calculate industrial margins, commonly defined as the difference between the "suggested price" and the Platts. The "suggested price" has two components: a fiscal one and an industrial one. It has been estimated by the Italian Union of Petrol Producers that the Platts reflects 67 percent of the industrial price, while the other 33 percent is attributable to distribution, storage, administrative steps and the petrol stations' margin. Taxes account for

\footnotetext{
9 Autorità Garante della Concorrenza e del Mercato, 18.1.2007, Case I681 - Prezzi dei carburanti in rete, Provvedimento no. 16370, Section IV, para. 27, available at http://www.agcm.it.

10 Platts is a division of the Information \& Media Services group of McGraw-Hill and a leading global provider of energy information that collects and publishes on a daily basis details on the prices of bids and offers for specific oil products and regions from traders and exchange platforms.

11 See for example the analysis of the composition of final retail prices into industrial and fiscal components by the Italian Petrol Union, available at http://www.unionepetrolifera.it/it/show/34/La\%20struttura\%20del\%20prezzo or the Pöyry (2009) report on EU fuel prices.
} 
approximately 58 percent of the final retail price in Italy and are the major component of the final price.

\section{Data}

We use two different datasets, the first of which is a dataset which consists of daily firm-specific pre-tax wholesale prices and industry level costs as reported by the Platts Cif Med. This data is summarized in Table 1 and will be used to analyze the pricing strategies adopted by the leader and the reaction of the competitors. The wholesale prices, plotted in Figure I, refer to the "suggested prices" of gasoline described above from the nine major companies ENI, Api, Erg, Esso, IP, Q8, Shell, Tamoil and Total from $1^{\text {st }}$ January 2003 until $15^{\text {th }}$ May 2005. As discussed above, the main source of costs for firms is the Platts, which represents the implicit opportunity cost to firms to sell their gasoline on the European wholesale market rather than to their petrol stations.

The second dataset consists of average aggregate retail gasoline prices for EU countries, which include taxes. This dataset is taken from the European Commission Oil Bulletin, which reports the prices of oil products across Europe on a weekly basis. ${ }^{12}$ The countries we consider to be the EU benchmark are the Netherlands, France, Germany, Austria, Belgium, Greece, Spain and Portugal for the period from January 2003 to May 2005. These prices include taxes and were collected weekly. A summary of the EU data per country is reported in Table 2, while a plot of the Brent, Italian and EU prices can be seen in Figure II.

\section{Tacit Collusion through Sticky Leadership Pricing}

We analyze the incidents relating to $6^{\text {th }}$ October 2004 (first vertical line in Figure I) when ENI publicly announced the adoption of a new pricing policy which consisted of fewer and larger price changes. ENI increased its average price change from $1 \%$ to $5.8 \%$ and increased the time lag between price changes from 6 days to 16 days. ENI declared that the purpose of this policy was to lower the short-term price-cost relation and to stabilize retail prices. ${ }^{13}$ About five months later in March 2005 (third vertical line in Figure I) the Italian Truckers' Association, FITA, complained to the Italian antitrust authority about high and aligned prices. ${ }^{14}$ About two years later, in January 2007, the Italian antitrust authority started an investigation into price fixing. Due

\footnotetext{
${ }^{12}$ For an in-depth analysis of the European gasoline market we refer to the report commissioned by the EU Commission and edited by Pöyry Energy Consulting in 2009.

13 Autorità Garante della Concorrenza e del Mercato, 18.1.2007, Case I681 - Prezæi dei carburanti in rete, Provvedimento no. 16370, Section VI, para. 42, available at http://www.agcm.it.

${ }^{14}$ Autorità Garante della Concorrenza e del Mercato, 18.1.2007, Case I681 - Prezæi dei carburanti in rete, Provvedimento no. 16370, Section I, para. 1, available at http://www.agcm.it.
} 
to the lack of evidence of direct communication between firms the antitrust authority decided to end the investigation in December 2007 without punishing ENI and its competitors for an antitrust violation. The authority could only achieve a commitment by the firms to reduce price transparency on the market. ${ }^{15}$

The aim of the empirical analysis is to describe the different pricing patterns which emerged after the leader's unilateral price commitment and to test whether this change caused a price increase. In the first part of the empirical analysis we focus on characterizing the main traits of the pricing behavior of firms and on the relation between the leader's and competitors' price changes. We test whether the standard deviation, competitors' alignment and the frequency and magnitude of price variations significantly changed after the policy and thus, whether competitors adopted the same pricing behavior as the leader. In addition we test for the emergence of leadership pricing by analyzing competitors' price reactions to price changes by the leader.

In the second part we test whether the new price pattern was pro-collusive and caused a price increase using a difference-in-differences method and a synthetic control group approach.

Throughout the empirical analysis we will use the date when ENI's competitors started to align to ENI (12 $2^{\text {th }}$ November 2004) as the beginning of the policy (second vertical line in Figure I) and not the date on which ENI announced its new pricing policy ( $6^{\text {th }}$ October 2004). This choice reflects the emergence of the new sticky-leadership pricing after the transition period characterized by ENI's price commitment and does not significantly affect our results. ${ }^{16}$

\subsection{Policy Change and Competitors' Alignment}

\subsubsection{Sticky-pricing}

Sticky pricing constitutes an important element in a strategy to sustain collusion. An advantage of sticky pricing is that it is straightforward to implement and that deviations can easily be detected and punished. In a series of theoretical papers Athey and Bagwell (2001, 2008), Athey et al. (2004) analyse dynamic collusive pricing. The key trade-off that emerges from the theoretical analysis of firms' incentives to engage in sticky pricing as collusive strategy is between productive efficiency that requires firms with lower costs to produce more and higher (aligned) prices under collusion. Under some parameter constellations the optimal equilibrium for firms is relatively

\footnotetext{
15 Autorità Garante della Concorrenza e del Mercato, 20.12.2007, Case I681 - Prezæi dei carburanti in rete, Provvedimento no. 17754, available at http://www.agcm.it.

${ }^{16}$ We ran all the regressions both including and excluding the "commitment" period (interval between the first two vertical lines in Figure I). The inclusion of this period neither changes the sign nor the significance level of the estimated coefficients.
} 
simple: all firms adopt a sticky pricing scheme and charge the consumers' reserve price. ${ }^{17}$ Thus, firms sacrifice productive efficiency to sustain a higher price level in the market. The theoretical prediction that collusion is linked to sticky pricing is confirmed by a series of empirical findings based on ex-post evidence of cartel pricing (Abrantes-Metz et al., 2006, Blanckenburg et al., 2011, Connor, 2005). In this section we provide statistical evidence according to which firms adopted sticky pricing after the new policy was introduced.

Table 3 reports the firms' absolute percentage price changes on days with price changes (columns 1 and 2) and the number of days between price changes (columns 4 and 5) before and after ENI's new policy respectively. In column 3 and 6 we report the difference (in italics) of the pre and post policy means of frequency and magnitude and the t-statistic (in bold). Before the policy firms' price changes were frequent and price changes were small. On average changes occurred every 5 days and the average price change was .8\%. After the new pricing policy, price changes occurred less frequently, on average every 9 days, and their amount became larger, namely $2.9 \%$. Performing the same analysis for each firm individually, we get the same results: all competitors significantly increased the magnitude of price changes and six out of eight competitors significantly increased the time lag between price changes which shows that competitors substantially adopted the leader's new pricing policy as can be seen in Figure I. ${ }^{18}$

In addition, we test whether the daily dispersion of prices across firms decreased after the policy, a common finding in cases of collusion. The right part of Figure III displays the kernel density distribution of the daily price standard deviation ${ }^{19}$ across firms before and after the policy was implemented. The dotted line indicates the price dispersion after the policy change and suggests a decrease in the dispersion after the policy. In contrast the mean price dispersion increased significantly during the period of sticky pricing. This result is explained by the increase in the magnitude of price changes, which caused huge spikes in price dispersion on days where ENI changed its prices. In fact while the mean price dispersion is significantly higher (.0022 versus .0015), the median is lower (.0012 versus .0015). While this might seem to contrast with our collusive hypothesis based on the positive relation between sticky-aligned prices and collusion, in Table 5 specification 1, we build a regression model which controls for current and lagged price changes by the leader. We find that the mean absolute percentage price difference between the leader and competitors significantly decreased after the policy, which is in line with collusive

\footnotetext{
${ }^{17}$ As usual in supergames, many different equilibria might emerge. In this paper we focus on the simplest strategy to sustain collusion, i.e. sticky-pricing. With other parameter configurations other (more complex) type of equilibria are possible.

18 Only one competitor, ERG, publicly declared that it would not directly follow ENI's new pricing strategy, see Autorità Garante della Concorrenza e del Mercato, 18.1.2007, Case I681 - Prezzi dei carburanti in rete, Provvedimento no. 16370, Section VI, para. 41.4, available at http://www.agcm.it.

19 Using the coefficient of variation yields the same results.
} 
leadership pricing. This result suggests that economic screens $s^{20}$ based on price mean-variance tests might fail to sufficiently take into account variations in the magnitude of price changes caused by focal pricing during collusive periods.

A shortcoming of sticky pricing models is that they do not address how colluding firms react and coordinate on exogenous cost and demand changes. In the next section we will demonstrate that ENI's (focal) price was used by its competitors to coordinate price changes.

\subsubsection{Leadership pricing}

Price leadership is "one of the most important institutions facilitating tacitly collusive pricing behavior" (Scherer and Ross, 1990, p. 346). Rotemberg and Saloner (1990) examine a differentiated oligopoly and demonstrate that price leadership facilitates collusion under asymmetric information and that it increases price rigidity. They conclude that such a pricing scheme has many positive attributes: first, it is easy to implement, second, it doesn't require communication, and third, it is very easy to detect deviations. Mouraviev and Rey (2011) study the role of price or quantity leadership in circumstances where firms can act either simultaneously or sequentially in an infinitely repeated setting for both Bertrand and Cournot competition. In line with Rotemberg and Saloner (1990) they highlight that leadership facilitates collusion.

We test whether ENI's commitment led to leadership pricing. The left part of Figure III shows the histogram of sum_aligned_compet ${ }_{t}$, the sum of aligned competitors. While pre-policy alignment, which is a count variable, seems to follow a Poisson distribution, the post-policy alignment distribution is more skewed to the right and seems to have a larger number of aligned firms. As sum_aligned_compet is an over-dispersed count variable that takes values from 0 (no competitor aligned) to 8 (all competitors aligned), we run a Negative Binomial Regression model to test if the number of aligned firms is higher after the policy. Specification 1 in Table 4 shows the result. The coefficient on PolicyChange is positive and highly significant, and computing the marginal effect shows that while the average number of perfectly aligned competitors is 1.95 , after the policy change it increases to 3.2 .

We now turn to dynamic price alignment and run two regression models to test whether the dynamic price response of competitors to price changes by the leader changed after the new policy. The key challenge when estimating competitors' responses is the endogeneity of ENI's price changes which might cause reverse causality. Thus, rather than claiming a causal interpretation of the regression coefficients we focus on testing a break in the leader-competitor pricing behavior. In particular, we are interested in testing whether the infrequent (but large)

${ }^{20}$ For a review of screens and their multiple applicability see Abrantes-Metz and Bajari (2009). 
price changes by the leader served as a focal price to coordinate competitors' price changes. In the first model we use a firm fixed effect logit regression to relate the binary decision by a firm to perfectly align its price to the leader's price to current and past price changes by the leader:

$$
\begin{aligned}
& P\left(\text { Align }_{i, t}=1 \mid \boldsymbol{Z}\right)=h\left(\beta_{0}+\beta_{1} \text { policy }_{t}+\sum_{k=0}^{6} \rho_{K}\left(\text { policy }_{t} * \text { ENIChangeP }_{t-k}\right)+\right. \\
& \left.\sum_{k=0}^{6} \pi_{K} \text { ENIChangeP }_{t-k}+\gamma_{i}\right)
\end{aligned}
$$

Where Align $_{i, t}$ is a binary indicating whether competitor $i$ charges the same price as the leader at day $t$, policy $y_{t}$ is a dummy being 1 after the policy was introduced and $E N I c h a n g e P_{t-k}$ is a dummy being 1 if the leader changed its price on day $t-k, \gamma_{i}$ are time-invariant firm fixed effects and $h(\cdot)$ is the logistic distribution. The estimation coefficients of the logit model and their marginal effects are in Table 4, specification 2.1 and 2.2 respectively, while in specification 2.3 we report the odds ratios. The key parameters of interest are $\rho_{K}$ which capture the competitors' dynamic price response to a price change by the leader after the policy. The average likelihood of a competitor aligning its price to the leader after the policy increased significantly by about $10 \%$. Most importantly, after the policy, on days where the leader changed its price, the average likelihood of a price alignment decreases by $16.1 \%$ and then gradually grows until it reaches 16.4 to $17.9 \%$ from the fourth to the sixth lag. The same results can be seen by looking at odds ratios in specification 3. This regression analysis confirms the "visual" dynamic price alignment presented in Figure I, where all major price changes by competitors where preceded by ENI's price change after the policy.

Because Align $_{i, t}$ is binary and narrowly defined (i.e. up to three decimal places) we also consider a continuous measure as the dependent variable, i.e. the absolute percentage price difference with respect to the leader $\left(\mid\left(\right.\right.$ Price $_{i, t}-$ Price $\left._{E N I, t}\right) /$ Price $\left._{i, t} \mid\right)$. To take into account possible asymmetries between positive and negative price changes we also run the regression distinguishing between positive and negative price changes. A problem with dividing the samples is that after the policy ENI changed its price only 10 times, including 6 negative and 4 positive price changes. The coefficients of the three OLS regressions using all, only positive, and only negative price changes is shown in Table 5, specifications 1, 3, and 5, respectively. The regression coefficients of specification 1 for the two time periods, before and after the policy, are plotted in Figure IV as a graphical analysis best depicts the average change in the dynamic alignment between periods. After the new policy, the average absolute percentage price difference to the leader was $4.59 \%$ on days where the leader changed its prices and then this 
difference decreases to $1.94 \%(1.38 \%)$ [.04\%] one (two) [three] day(s) after the leader changes its prices. Finally, this difference becomes insignificant on the fourth price-change lag. This relation is not present before the policy, where the competitors' absolute percentage price difference to the leader is mostly constant. In specification 2 and 3 we use the percentage price difference to the leader and consider positive and negative price changes respectively. The coefficients present a similar pattern as in specification 1. After the policy, the average difference to the leader after positive (negative) price changes is $-6.52 \%$ (2.69\%) indicating that the magnitude of the leader's positive changes is larger than negative changes. Similar to specification 1, the absolute value of these differences decreases after a few lags but the coefficients after the $4^{\text {th }}$ lag become insignificant only after positive price changes. For negative changes competitors' prices slightly but significantly undercut the leader's price by $-.05 \%$.

The estimates presented above show that the competitors' price reactions with respect to the leader's price changes changed significantly after the policy. Confirming the graphical evidence in Figure I, competitors changed and aligned their prices within a few days after the leader changed its prices, a common pricing scheme referred to as leadership pricing, adopted to coordinate price changes and facilitate alignment.

\subsection{The Effect of the New Pricing Policy on the Price Level}

The previous section focused on the coordination mechanism represented by the stickyleadership pricing which emerged after the announced new pricing policy and its relation to theoretical and empirical literature on how cartels work. We now turn to the pro-collusive effect of the new pricing behavior. The aim of this section is to causally evaluate the effect of ENI's sticky-leadership pricing policy on Italian prices.

The fundamental problem is that we can at most observe one treatment group (Italy) and have no information as to what would have happened without the introduction of the policy. ${ }^{21}$ As markets and firms are simultaneously hit by a multiplicity of shocks our main concern is that ENI might be responding to shocks which are unobservable to the econometrician. Thus, the change in the post-policy price level in Italy might have been as well caused by omitted variables. To control for such unobserved shocks we need to relate Italian prices to a control group which received no treatment, the standard procedure in the literature on cartel detection. ${ }^{22}$ In the case of the Italian petrol market, given that prices respond to the same cost shocks across national

\footnotetext{
21 For a discussion on problems and methods of evaluating different kind of policies see Imbens and Wooldridge (2009).

22 The cartel detection literature takes comparable industries to detect "suspicious" pricing patterns or to evaluate the ex-post effects of illegal price coordination. For example Christie and Schultz (1994) compare the dealers' bid-ask spread in the Nasdaq to its equivalent in the Dow Jones, while Porter and Zona (1999) compare bidding behavior of colluding firms with non-colluding firms.
} 
markets, and that the goods are homogeneous and traded in the same currency, we can use the gasoline prices of EU Member States as a benchmark. This permits us to causally link ENI's new pricing policy to the industry's profits. Using panel data from nine EU Member States we estimate the effect of ENI's price policy using a dif-in-dif model. ENI's policy change in Italy induces a deviation from this common trend, and although the treatment country (Italy) and control countries $(\mathrm{EU})$ can differ substantially, all the time invariant country level differences ${ }^{23}$ are captured by the (EU countries) fixed effects. The key identifying assumption is that "market trends" would be the same in each of the selected EU Member States in the absence of a treatment (price policy change). This means that we assume that ENI's policy and the subsequent new pricing pattern were not correlated to any unobservable market shock in Italy. This assumption is justified by the fact that ENI declared that the reason they were introducing sticky pricing was the increased volatility of the major cost factor, the Platts. ${ }^{24}$ The Platts is not an Italyspecific cost index and its volatility ultimately depends on the international price of crude oil. Thus, exogenous shocks to the Platts are not limited to the Italian petrol market but impact on other countries as well.

A common shortcoming of the dif-in-dif model has been the sensitivity of its results to estimation assumptions. In our case one might question a sufficient "similarity" between the Italian and the control group gasoline market. The selection of a control group is usually done on the basis of subjective measures of similarity between affected and unaffected groups. We address this issue using an "optimal" weighted average of the available control units. This estimation technique called "synthetic control group" was developed by Abadie and Gardeazabal (2003) and Abadie, Diamond, and Hainmueller (2010). This inferential method constructs a data-driven synthetic control group using weights of European prices in order to minimize the pre-treatment differences between the Italian price and that of the synthetic control group. Intuitively, the synthetic control group represents a "better" or "more similar" comparison group for Italian prices than any single EU price. ${ }^{25}$ In addition this method illustrates the similarities and the relative contribution of each control group in forming a benchmark. Thus, it lowers the discretion in selecting a control group and forces the researchers to show the data-driven weights of each group. This estimation procedure allows us to construct a data-driven, and therefore, more objective control group and to compare the estimates for the effect of the new policy on Italian prices across specifications.

\footnotetext{
23 The Italian gasoline market differs in some respect from other EU countries as summarized by the report of Pöyry (2009). Italy has the lowest throughput per site and hypermarkets own considerably more stations in the rest of the EU than in Italy.

${ }^{24}$ Autorità Garante della Concorrenza e del Mercato, 18.1.2007, Case I681 - Prezzi dei carburanti in rete, Provvedimento no. 16370, Section VI para. 42; available at http://www.agcm.it.

${ }_{25}$ Formally, the weights are constructed to minimize the difference between price $_{I T, t<\text { policy }}$ and $\sum_{j=2}^{9} w_{j}$ price $_{j, t<\text { policy }}$.
} 
In the main regression model we estimate a dif-in-dif using panel data with weekly price observations from $9 \mathrm{EU}$ countries over a time period of 29 months. The main regression equation is:

$$
\text { price }_{i, t}=\beta_{0}+\beta_{1}\left(I T * \text { policy }_{t}\right)+\beta_{2} \text { policy }_{t}+\gamma_{i}+X_{t} \beta+\varepsilon_{i, t}
$$

The dependent variable, price $_{i, t}$, refers to the price of country $i$ at week $t$. IT $*$ polic $_{t}$ is an interaction term between two dummy variables indicating Italy and the new pricing policy respectively. policy $y_{t}$ is a time dummy that switches to 1 after the policy change. $\gamma_{i}$ are country fixed effects and $X_{t}$ is a vector of control variables that vary over time but not across countries. In the full specification $X_{t}$ contains lagged values of the Brent (crude oil), a linear time trend, month and year fixed effects. In some specifications we will add only a dummy for the Italian price so that $\gamma_{i}=$ Italy in order to estimate the "Italian mark-up," while in other specifications we will add all other country dummies and leave out Italy. As already pointed out this "country mark-up" reflects structural, time-invariant differences across countries, e.g. wages and taxes.

The key parameter of interest is $\beta_{1}$, the interaction between the time after the policy change and a dummy indicating Italy's price. $\beta_{1}$ captures the pre and post policy price difference between the treated country (Italy) and the control group (EU), controlling for cost changes (Brent) and seasonal effects. If sticky and leadership pricing were used as a facilitating device to sustain a supra-competitive price level, we would expect $\beta_{1}$ to be positive and significant.

The firms' cost structure across countries depends on three cost sources that can be considered separately. The main source of costs, crude oil, is the same for all countries and using the standard SBIC and AIC criteria, in line with previous literature, we added four weeks lags to account for dynamic price adjustment to costs. The second source of costs are time independent (unobserved) country-specific costs, such as wages and transport costs, that will be captured by the country fixed effect. Finally there are unobserved time varying firm-level cost shocks which we assume to be uncorrelated with ENI's new policy.

Table 6 reports the estimated coefficients for the fixed effect model specified by (2) with standard errors clustered at country level in parenthesis. Specifications 1 to 3 use EU countries fixed effects and thus show the average price difference of each EU country as compared to Italy, while specifications 4 to 6 use a dummy for Italy and leave the other EU countries out. All but one country, the Netherlands, have a significantly lower price level than Italy. Greece (France) is the country with the lowest (largest) price difference to Italy, namely about $-4.6 €(-77.9 €)$ per 
1000 liters. From specifications 4 to 6 it emerges that Italy has a structural price difference of about $30 €$ per 1000 liters with respect to the other eight EU countries.

The parameter of the key variable of interest, $I T *$ polic $_{t}$, is positive and highly significant across specifications. The inclusion of current and lagged costs, i.e. the Brent, and month and year fixed effects does not affect the estimate of $\beta_{1}$. The effect of ENI's policy was to increase prices by about $9.8 €$ per 1000 liters, which corresponds to a 3\% price increase when controlling for costs, seasonality and a time trend. This is in line with the collusive hypothesis based on theoretical and empirical literature discussed above. Sticky and leadership pricing were used as a means to coordinate and raise prices.

We compare these findings with the synthetic control group approach by Abadie and Gardeazabal (2003) and Abadie, Diamond, and Hainmueller (2010). In Figure V we plot the Italian and the synthetic control price (left part) and their difference (right part). The vertical line represents the date of ENI's policy change. The synthetic control (by construction) tracks the Italian price well before the policy change. After the policy change the lines seem to diverge more and the difference between the Italian price and the synthetic control increased. Table 7 reports the estimates of the weights, pre and post treatment average prices and their difference. The Netherlands's price most closely resembles the Italian one, and thus has a weight of $81 \%$, while all other countries oscillate between weights of 5.8\% (Greece) and 1.4\% (Germany). Whereas the pre-treatment synthetic price is by construction very close to the Italian price, the post-treatment price differences are large. After the policy change, Italian prices rose by $8.88 €$ per 1000 Liters with a standard error of 2.84 . This positive price difference is significant at the $5 \%$ level with a pvalue of .014 and is in line with the dif-in-dif estimation discussed above. This confirms that our findings of a significant and positive price increase are not the result of a subjective choice of control groups.

One concern with the dif-in-dif model is that prices follow an $\operatorname{AR}(1)$ process and thus the error terms are correlated over time. Performing an augmented Dickey-Fuller test on the Italian and European prices and the Brent, we cannot reject the null hypothesis of a unit root at conventional confidence levels; in contrast the first difference between the aforementioned variables is stationary. To account for the error term correlation we estimate a model in which all variables are stationary and the dependent variable is defined as the price difference between the Italian price and that of the synthetic control group in week $t$. We regress this stationary difference on the current and lagged first differences of the crude oil, $\Delta B r e n t_{t-j}$, a time trend, $\tau_{t}$, and our key variable of interest, policy $y_{t}$. The time series regression model we estimate is: 


$$
\text { price }_{I T-\text { SynthCont }, t}=\beta_{0}+\beta_{1} \text { polic }_{t}+\tau_{t}+\sum_{j=0}^{4} \theta_{j} \Delta \text { Brent }_{t-j}+\epsilon_{t}
$$

The synthetic control group discussed above represents an "optimal benchmark" and price $_{I T-\text { SynthCont, } t}$ can be thought of as the daily price deviation of the Italian price relative to its pre-treatment optimal benchmark. The effect of the new price policy controlling for current and lagged cost differences will be captured by $\beta_{1}$. Due to the weekly level of the time series and the relatively short time horizon, 29 months with some gaps due to public holidays, we cannot add year and month fixed effects in (3) as we have insufficient data, 94 observations, but instead maintain the time trend. Table 8 reports the estimated coefficients. Moving from specification 1 to 3 we first add current and lagged cost differences and finally a time trend. In line with the difin-dif results all the coefficients on polic $y_{t}$ are significant at the $1 \%$ level and positive. Once we control for current and lagged costs, first differences and a trend the coefficient grows from 8.8 to 12.5 .

Our regression analysis confirms that after the introduction of the sticky pricing policy Italian prices rose with respect to the period before the policy change and controlling for a synthetic control group or EU prices, costs and month and year fixed effects. The regression results confirm that the new policy had a positive and significant effect on Italy's gasoline prices. Through sticky and leadership pricing firms have coordinated their price changes and significantly increased their price levels relative to the EU.

\subsection{Robustness Check: Productive Efficiency vs. High (Rigid) Prices}

At least since the first theoretical models of the kinked demand curve there has been a longstanding feeling that collusion is associated with price rigidity. Intuitively, "to collude" means attributing a higher weight to keeping high prices rather than setting own prices in accordance with demand and firm-level costs. This result has been confirmed in different dynamic settings by a series of papers (Athey and Bagwell, 2001, 2008, Athey et al., 2004). While none of these papers perfectly match the setting of the Italian petrol market, the common prediction of the theoretical literature is that the best collusive scheme consists of rigid prices at the expense of productive efficiency. Thus, firms price independently of their own cost type and charge the consumers' 
reservation price. The key trade-off is between productive efficiency, whereby the firm with the lowest costs serves the market more, and high (rigid) prices that do not reflect firm-level costs. ${ }^{26}$

Our collusive hypothesis states that firms adopted sticky leadership pricing to increase their margins at the expense of productive efficiency. As a robustness check we test whether our hypothesis can be rejected using daily Italian firm level prices. We test two predictions of our sticky leadership collusive hypothesis: first, margin differences with respect to the price leader, ENI, must become insignificant after the policy change and second, margins must increase. The intuition behind this test is that firms aim at increasing their margins by colluding. Firms with higher (lower) costs must have higher (lower) prices in a non-collusive equilibrium, but have the same profit-maximizing (rigid) price under a collusive scheme. ${ }^{27}$ Thus, at least some of the competitors' fixed effects should be significant if they price independently, but insignificant if they follow the leader's price. In regression model (4) $\beta_{2}$ captures the effect of the policy on margins, while the competitors' fixed effects capture cost differences with respect to the leader. Because of the asymmetric market shares this difference should be positive compared to the market leader (the low cost firm) in a non-optimal collusive equilibrium and insignificant in an optimal collusive sticky pricing equilibrium. ${ }^{28}$ As we showed that ENI was the price leader we test whether firms increased their margins but decreased the average margin difference with respect to ENI. ${ }^{29}$

$$
\operatorname{margin}_{i, t}=\beta_{0}+\beta_{i}\left(\gamma_{i} * \text { policy }_{t}\right)+\beta_{2} \text { policy }_{t}+\gamma_{i}+\tau_{t}+\varepsilon_{i, t}
$$

$\gamma_{i}$ are firm fixed effects, policy $y_{t}$ is a dummy that switches to one after the policy was implemented and $\tau_{t}$ is a time trend. The key parameters of interest are $\beta_{2}$ and $\beta_{i}$ (see specification 3) that test whether margins were higher and whether the competitors' margin differences changed with respect to the leader after the policy respectively. The results are reported in Table 9. The dependent variable, $\operatorname{margin}_{i, t}$, is stationary and defined as the daily

\footnotetext{
${ }^{26}$ Interestingly, Marshall et al. (2008) analyse the role of price announcements in the vitamins cartel and found that during the cartel phase the likelihood of a price announcement is driven by the length of time between announcements, rather than by cost or demand changes. Their evidence provides empirical support for the hypothesis that during a cartel firms don't price following their own costs and thus the price difference across firms should decrease. Slade (1992) analysed dynamic models of tacit collusion in Vancouver's gasoline market and concluded that between price wars prices were very stable and uniform across firms.

${ }^{27}$ Note that this is equivalent to having higher margins as the major source of costs, i.e. the Platts, is the same for all firms. In addition note that firms are capacity constrained and consumers face search costs, thus the low cost firm cannot serve the whole market even though it charges the lowest price.

${ }^{28}$ Even though we don't have information on firm level costs, market shares are very asymmetric. ENI has about $35 \%$ market shares while the second (third) largest firm has $16 \%(11 \%)$, and all other firms range between $5 \%$ and $8 \%$.

${ }^{29}$ We obtain similar results if we test margin differences across all firms (results not shown).
} 
difference between firm's $i$ price and the Platts. ${ }^{30}$ In the first (second) specification we perform the regression for the pre (post) policy period only. In specification 3 we report the results of model (4) and thus include both periods, (time invariant) fixed effects and their interaction with the policy dummy. Specification 3 tests for a structural break in the margin differences compared to the leader after the policy.

In line with the previous regressions firms' average margins significantly increased after the new policy by about $22 €$ per 1000 liters. ${ }^{31}$ More importantly, the estimates seem to confirm that firms exchanged productive efficiency to maintain higher prices. As ENI acted as the price leader and has the largest market shares we can reasonably assume that it is the low-cost firm and accordingly it should have the lowest margins in the market. In fact, competitors' margins were significantly higher than ENI's margins before the policy (specification 1) with the exception of one firm, ERG. This difference changes sign (from positive to negative) and becomes insignificant for all firms after the policy implementation (specification 2). This result is confirmed in specification 3 where we include both time periods. The difference between the leader's and its competitors' margins becomes insignificant as firms adopt sticky-leadership pricing which lowers productive efficiency but increases the level of margins in the industry, as showed by the positive and significant estimate on policy $y_{t}$ in specification 3 . These results provide further evidence that the nature of ENI's new pricing policy was pro-collusive.

\section{Conclusion}

How firms set prices and coordinate price changes in order to tacitly collude in oligopolistic markets has been a perennial topic both for economics and antitrust policy. This paper examines dynamic pricing in the Italian wholesale gasoline market and highlights the importance of endogenous sticky price commitment and leadership pricing in tacit collusion.

We investigate the role of sticky-leadership pricing as a coordination mechanism to bring about and sustain (tacit) collusion. After its unilateral sticky-pricing commitment the market leader, ENI, did not change its price for 57 days irrespective of cost changes while competitors kept cost-based pricing. Sticky and leadership pricing emerged as the new pricing equilibrium and was adopted by all firms. Firms coordinated price changes through the leader's (focal) price and this coordination resulted in a price increase relative to EU prices.

\footnotetext{
${ }^{30}$ We also ran a similar regression (results not shown) using firms' prices as the dependent variable and controlling for current and lagged costs. The findings are unchanged with respect to model (5).

31 If we leave out the trend (results not shown) the coefficient on the policy dummy is smaller, $16 €$ per 1000 liters, but still significant at the $1 \%$ level.
} 
In the first part of the empirical analysis we characterize the main traits of firms' pricing and the leader-competitor pricing interdependence. We show that after the new policy was implemented, firms increased the magnitude and the time lag between price changes, and thus adopted the same pricing policy as the leader had announced. In addition, we demonstrate that competitors adjusted their prices following the leader's price changes after but not before the implementation of the new policy. In the second part of the empirical analysis we focus on the effects of the newly emerged sticky-leadership pricing on the level of Italian prices with respect to a control group. We use a dif-in-dif and a synthetic control group approach to evaluate whether this sticky leadership pricing resulted in higher prices. In all specifications we find that prices significantly increased, with estimates ranging from 8 to $12 €$ per 1000 liters. Combined, this price coordination mechanism and the subsequent price increase show that the effect of the unilateral price commitment was to tacitly collude through facilitating price coordination.

These findings cast serious doubts on the effectiveness of cartel enforcement that depends on evidence of (explicit) communication. Tacit collusion appears to be a "natural" way in which oligopolistic markets work. Firms in oligopolistic markets can use their market power to influence competitors' conduct and collude through specific pricing strategies. How to address such unilateral conduct with welfare-decreasing effects without unduly limiting the freedom of price setting in oligopolies remains an unanswered question though. 


\section{References}

Abadie, Alberto, and Javier Gardeazabal (2003). The Economic Costs of Conflict: A Case Study of the Basque Country. American Economic Review 93(1), 113-132.

Abadie, Alberto, Alexis Diamond, and Jens Hainmueller (2010). Synthetic Control Methods for Comparative Case Studies: Estimating the Effect of California's Tobacco Control Program. Journal of the American Statistical Association 105(490), 493-505.

Abrantes-Metz, Rosa M., and Patrick Bajari (2009). Screens for Conspiracies and Their Multiple Applications. Antitrust Magazine 24(1), 66-71.

Abrantes-Metz, Rosa M., Luke M. Froeb, John F. Geweke, and Christopher T. Taylor (2006). A Variance Screen for Collusion. International Journal of Industrial Organization 24(3), 467-486.

Athey, Susan, and Kyle Bagwell (2001). Optimal Collusion with Private Information. RAND Journal of Economics 32(3), 428-465.

Athey, Susan, and Kyle Bagwell (2008). Collusion with Persistent Cost Shocks. Econometrica 76(3), 493-540.

Athey, Susan, Kyle Bagwell, and Chris Sanchirico (2004). Collusion and Price Rigidity. Review of Economic Studies 71(2), 317-349.

Bachmeier, Lance J., and James M. Griffin (2003). New Evidence on Asymmetric Gasoline Price Responses. Review of Economics and Statistics 85(3), 772-776.

Blanckenburg, Korbinian von, Alexander Geist, and Konstantin Kholodilin (2011), The Influence of Collusion on Price Changes: New Evidence from Major Cartel Cases. German Economic Review 13(3), 245-256.

Bolotova, Yuliya V. (2009). Cartel overcharges: An empirical analysis. Journal of Economic Behavior \& Organization 70(1-2), 321-341.

Borenstein, Severin, A. Colin Cameron, and Richard Gilbert (1997). Do Gasoline Prices Respond Asymmetrically to Crude Oil Price Changes? Quarterly Journal of Economics 112(1), 305-339.

Christie, William G., and Paul H. Schultz (1994). Why Do Nasdaq Market Makers Avoid OddEighth Quotes? Journal of Finance 49(5), 1813-1840.

Connor, John M. (2005). Collusion and Price Dispersion. Applied Economics Letters 12(6), 335-338.

Duso, Tomaso, Lars-Hendrik Röller, and Jo Seldeslachts (2012). Collusion through Joint R\&D: An Empirical Assessment. Review of Economics and Statistics, forthcoming.

Eckert, Andrew (2003). Retail Price Cycles and the Presence of Small Firms. International Journal of Industrial Organization 21(2), 151-170

Fonseca, Miguel A., and Hans-Theo Normann (2012). Explicit vs. Tacit Collusion - The Impact of Communication in Oligopoly Experiments. European Economic Review, forthcoming.

Harrington, Joseph E., Jr. (2008). Detecting Cartels. In Paolo Buccirossi (ed.), Handbook in Antitrust Economics, MIT Press, 213-258.

Imbens, Guido W., and Jeffrey M. Wooldridge (2009). Recent Developments in the Econometrics of Program Evaluation. Journal of Economic Literature 47(1), 5-86.

Knittel, Christopher R., and Victor Stango (2003). Price Ceilings as Focal Points for Tacit Collusion: Evidence from Credit Cards. American Economic Review 93(5), 1703-1729.

Levenstein, Margaret C., and Valerie Y. Suslow (2006). What Determines Cartel Success? Journal of Economic Literature 44(1), 43-95. 
Lewis, Matthew S. (2012). Price Leadership and Coordination in Retail Gasoline Markets with Price Cycles. International Journal of Industrial Organization 30(4), 342-351.

Marshall, Robert C., Leslie M. Marx, and Matthew E. Raiff (2008). Cartel Price Announcements: The Vitamins Industry. International Journal of Industrial Organization 26(3), 762-802.

Maskin, Eric, and Jean Tirole (1988). A Theory of Dynamic Oligopoly, II: Price Competition, Kinked Demand Curves, and Edgeworth Cycles. Econometrica 56(3), 571-599.

Mouraviev, Igor, and Patrick Rey (2011). Collusion and Leadership. International Journal of Industrial Organization 29(6), 705-717.

Noel, Michael D. (2007). Edgeworth Price Cycles, Cost-based Pricing, and Sticky Pricing in Retail Gasoline Markets. Review of Economics and Statistics 89(2), 324-334.

Pöyry (2009). Survey of the Competitive Aspects of Oil and Oil Product Markets in the EU. A report to Directorate-General Energy and Transport of the European Commission.

Porter, Robert, and Douglas Zona (1999), Ohio School Milk Markets: An Analysis of Bidding, RAND Journal of Economics 30(2), 263-288.

Rotemberg, Julio J., and Garth Saloner (1990). Collusive Price Leadership. Journal of Industrial Economics 39(1), 93-111.

Scherer, Frederic M., and David Ross (1990). Industrial Market Structure and Economic Performance. $3^{\text {rd }}$ ed., Houghton Mifflin.

Slade, Margaret E. (1992). Vancouver's Gasoline-Price Wars: An Empirical Exercise in Uncovering Supergame Strategies. Review of Economic Studies 59(2), 257-276.

Tappata, Mariano (2009). Rockets and Feathers: Understanding Asymmetric Pricing. RAND Journal of Economics 40(4), 673-687.

Wang, Zhongmin (2009). (Mixed) Strategy in Oligopoly Pricing: Evidence from Gasoline Pricing Cycles Before and Under a Timing Regulation. Journal of Political Economy 117(6), 9871030.

Zitzewitz, Eric (2012). Forensic economics. Journal of Economic Literature 50(3), 731-769. 


\section{Appendix: Tables and Figures}

Table 1: Summary Statistics Italian Prices

\begin{tabular}{|c|c|c|c|c|c|}
\hline Variable & Mean & St. Dev. & Min & Max & Obs. \\
\hline ENI & 0.375 & 0.0400 & 0.310 & 0.476 & 866 \\
\hline API & 0.378 & 0.0397 & 0.313 & 0.476 & 866 \\
\hline ERG & 0.376 & 0.0401 & 0.312 & 0.481 & 866 \\
\hline ESSO & 0.376 & 0.0398 & 0.313 & 0.476 & 866 \\
\hline IP & 0.377 & 0.0396 & 0.313 & 0.476 & 866 \\
\hline Q8 & 0.377 & 0.0399 & 0.312 & 0.476 & 866 \\
\hline SHELL & 0.377 & 0.0402 & 0.313 & 0.476 & 866 \\
\hline TAMOIL & 0.377 & 0.0399 & 0.310 & 0.476 & 866 \\
\hline TOTAL & 0.378 & 0.0398 & 0.313 & 0.476 & 866 \\
\hline Platts Cif. Med. & 0.228 & 0.0391 & 0.159 & 0.340 & 866 \\
\hline Nr. Aligned Firms & 2.206 & 2.446 & 0 & 8 & 866 \\
\hline Aver. Price Dif. & 0.00250 & 0.00346 & 0 & 0.0404 & 866 \\
\hline St. Dev. Prices & 0.00174 & 0.00165 & 0 & 0.0205 & 866 \\
\hline
\end{tabular}

Table 1 reports the summary statistics of "suggested" daily firm level pre-tax prices in the Italian gasoline market from January 2003 to May 2005. The units of observation are Euro per liter.

Table 2: Summary Statistics EU Prices

\begin{tabular}{llllll}
\hline Variable & Mean & St. Dev. & Min & Max & Obs. \\
\hline Italy & 368.9 & 39.40 & 308.1 & 466.3 & 119 \\
Belgium & 328.3 & 39.18 & 255.6 & 421.1 & 119 \\
Germany & 312.6 & 39.14 & 254.8 & 387.5 & 119 \\
Spain & 338.0 & 37.54 & 280.3 & 410.5 & 119 \\
France & 288.9 & 39.11 & 231.8 & 383.6 & 119 \\
Greece & 362.0 & 39.61 & 296.2 & 453.8 & 119 \\
Netherlands & 371.9 & 40.29 & 310 & 464.5 & 119 \\
Portugal & 334.0 & 38.01 & 280.7 & 414.5 & 119 \\
Austria & 348.6 & 38.52 & 290.3 & 431.5 & 119 \\
Mean EU Price & 335.5 & 37.46 & 285.3 & 414.1 & 119 \\
Brent & 187.6 & 34.46 & 132.3 & 273.0 & 119 \\
\hline Table 2 reports summary statistics of weekly EU Prices from January 2003 to May 2005. The \\
units of observation are Euros per 1000 liters.
\end{tabular}


Table 3: Frequency and Magnitude of Price Changes

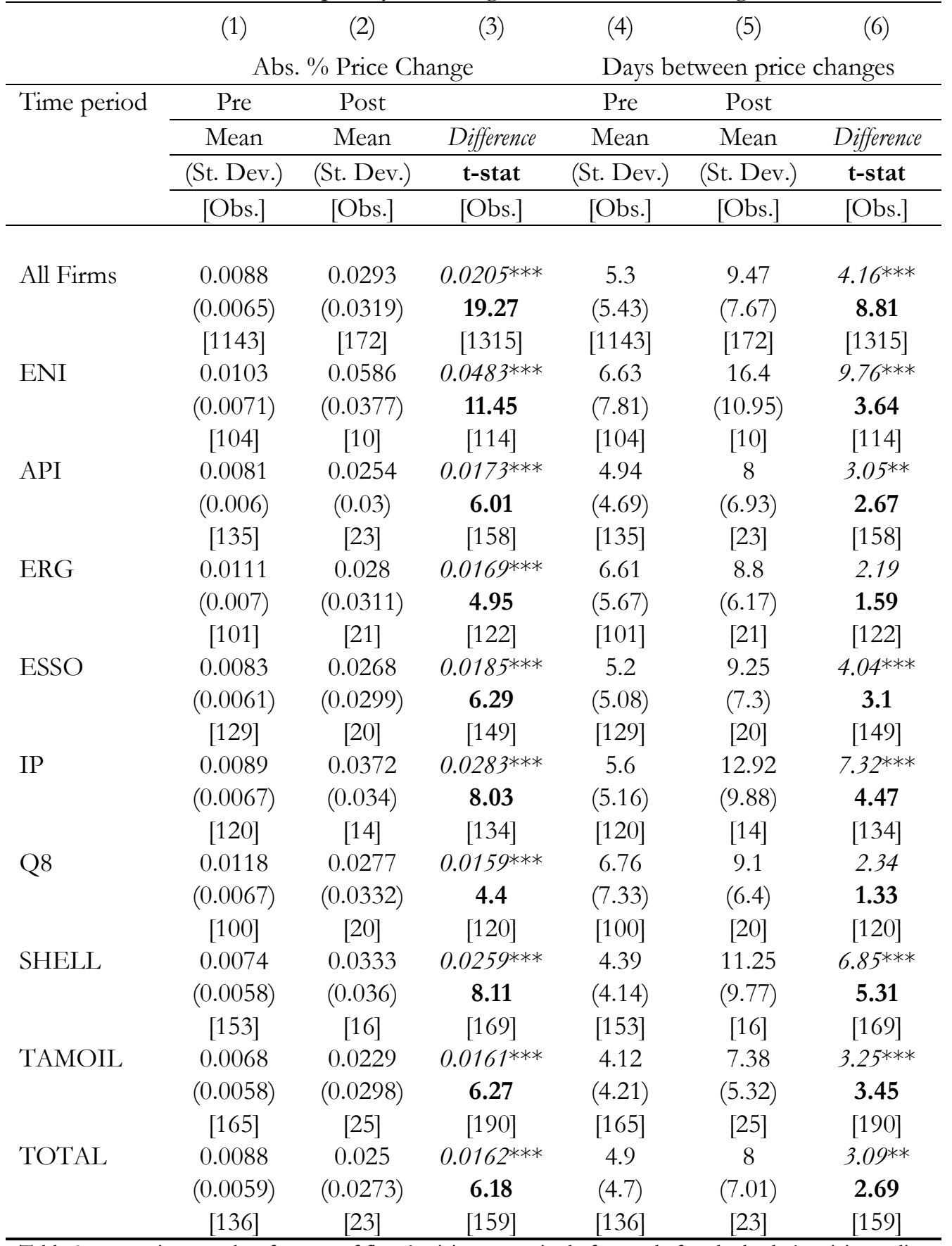

Table 3 summarizes two key features of firms' pricing strategies before and after the leader's pricing policy change. Columns 1 and 2 report the absolute mean price change on days with price changes for all firms (first row) and at the firm level. Columns 4 and 5 report the average days between price changes. In Columns 3 and 6 we calculate the pre and post policy differences of these two variables and the t-statistic testing whether the difference is significantly different. In square brackets we report the number of observations. 
Table 4: Price Leadership (1)

\begin{tabular}{|c|c|c|c|c|}
\hline Dependent Variable & $\begin{array}{l}\text { (1) } \\
\text { Number of aligned } \\
\text { firms }\end{array}$ & $\begin{array}{l}(2.1) \\
\text { Firm } \\
\text { aligned }\end{array}$ & $\begin{array}{l}(2.2) \\
\text { Firm } \\
\text { aligned }\end{array}$ & $\begin{array}{l}(2.3) \\
\text { Firm } \\
\text { aligned }\end{array}$ \\
\hline Regression Model & Negative Binomial & $\begin{array}{l}\text { FE Logit / } \\
\text { Coef. }\end{array}$ & $\begin{array}{c}\text { Marg. } \\
\text { Effects }\end{array}$ & $\begin{array}{c}\text { FE Logit / Odds } \\
\text { Ratios }\end{array}$ \\
\hline Policy Change & $\begin{array}{c}0.539 * * * \\
(0.0898)\end{array}$ & $\begin{array}{c}0.547 * * * \\
(0.0794)\end{array}$ & $\begin{array}{c}.1008^{* * *} \\
(.016)\end{array}$ & $\begin{array}{c}1.728^{* * *} \\
(.137)\end{array}$ \\
\hline \multicolumn{5}{|l|}{$\begin{array}{l}\text { Policy*Leader changes } \\
\text { price dummy }\end{array}$} \\
\hline Lag 0 & & $\begin{array}{c}-1.512 * * * \\
(0.393)\end{array}$ & $\begin{array}{c}-.161 * * * \\
(.023)\end{array}$ & $\begin{array}{l}.220 * * * \\
(.086)\end{array}$ \\
\hline Lag 1 & & $\begin{array}{r}-0.0321 \\
(0.262)\end{array}$ & $\begin{array}{l}-.0054 \\
(.043)\end{array}$ & $\begin{array}{l}.968 \\
(.253)\end{array}$ \\
\hline Lag 2 & & $\begin{array}{c}0.158 \\
(0.265)\end{array}$ & $\begin{array}{c}.027 \\
(.048)\end{array}$ & $\begin{array}{l}1.171 \\
(.31)\end{array}$ \\
\hline Lag 3 & & $\begin{array}{c}0.560^{* *} \\
(0.272)\end{array}$ & $\begin{array}{l}.109^{*} \\
(.059)\end{array}$ & $\begin{array}{c}1.751 * * \\
(.475)\end{array}$ \\
\hline Lag 4 & & $\begin{array}{c}0.801 * * * \\
(0.265)\end{array}$ & $\begin{array}{l}.164 * * * \\
(.062)\end{array}$ & $\begin{array}{c}2.23 * * * \\
(.592)\end{array}$ \\
\hline Lag 5 & & $\begin{array}{c}0.762 * * * \\
(0.265)\end{array}$ & $\begin{array}{l}.155^{* *} \\
.061)\end{array}$ & $\begin{array}{c}2.144 * * * \\
(.569)\end{array}$ \\
\hline $\operatorname{Lag} 6$ & & $\begin{array}{c}0.864 * * * \\
(0.267)\end{array}$ & $\begin{array}{l}.179 * * * \\
(.063)\end{array}$ & $\begin{array}{c}2.375^{* * *} \\
(.634)\end{array}$ \\
\hline \multicolumn{5}{|l|}{$\begin{array}{l}\text { Leader changes price } \\
\text { dummy }\end{array}$} \\
\hline Lag 0 & & $\begin{array}{c}-0.432 * * * \\
(0.101)\end{array}$ & $\begin{array}{c}-.066^{* * *} \\
(.014)\end{array}$ & $\begin{array}{c}.648^{* * *} \\
(.065)\end{array}$ \\
\hline Lag 1 & & $\begin{array}{c}-0.276 * * * \\
(0.0959)\end{array}$ & $\begin{array}{c}-.044 * * * \\
(.014)\end{array}$ & $\begin{array}{l}.758 * * * \\
(.072)\end{array}$ \\
\hline $\operatorname{Lag} 2$ & & $\begin{array}{l}-0.117 \\
(0.0926)\end{array}$ & $\begin{array}{l}-.019 \\
(.014)\end{array}$ & $\begin{array}{c}.889 \\
(.082)\end{array}$ \\
\hline Lag 3 & & $\begin{array}{c}-0.292 * * * \\
(0.0945)\end{array}$ & $\begin{array}{c}-.046^{* * * *} \\
(.014)\end{array}$ & $\begin{array}{c}.746 * * * \\
(.07)\end{array}$ \\
\hline Lag 4 & & $\begin{array}{c}-0.337 * * * \\
(0.0966)\end{array}$ & $\begin{array}{c}-.053^{* * *} \\
(.014)\end{array}$ & $\begin{array}{l}.713 * * * \\
(.069)\end{array}$ \\
\hline Lag 5 & & $\begin{array}{c}-0.336 * * * \\
(0.0969)\end{array}$ & $\begin{array}{c}-.053 * * * \\
(.014)\end{array}$ & $\begin{array}{c}.714 * * * \\
(.069)\end{array}$ \\
\hline $\operatorname{Lag} 6$ & & $\begin{array}{c}-0.463 * * * \\
(0.101)\end{array}$ & $\begin{array}{c}-.071 * * * \\
(.014)\end{array}$ & $\begin{array}{l}.628^{* * *} \\
(.063)\end{array}$ \\
\hline Ln_alpha & $\begin{array}{l}-0.238^{* *} \\
(0.0953)\end{array}$ & & & \\
\hline $\begin{array}{c}\text { Firms Fixed Effects } \\
\text { Constant }\end{array}$ & $\begin{array}{c}0.554 * * * \\
(0.0447)\end{array}$ & Yes & Yes & $\begin{array}{l}\text { Yes } \\
.325^{* * *} \\
(.029)\end{array}$ \\
\hline $\begin{array}{l}\text { Observations } \\
\text { R-squared }\end{array}$ & 866 & 6,928 & 6,872 & 6,872 \\
\hline
\end{tabular}

Table 4 reports the estimation results of regression model (1). It tests whether ENI's competitors changed their pricing behaviour in response to the sticky pricing policy. Note that policyt turns to 1 after $12^{\text {th }}$ November, the date on which most competitors started to follow ENI's new policy and not on the date the policy was announced, $6^{\text {th }}$ October. The choice of the beginning of the treatment period does not change the results significantly. The first specification uses a negative binomial model to test whether the number of competitors perfectly aligned to the leader increased after the policy change. Results are in line with the t-test presented in Section V.3. In the second and third column we report the regression coefficients and marginal effects of the fixed-effects logit regression model (1). In the last column we perform the same regression using a different variable, the absolute percentage price difference with respect to the leader. For a graphical representation of the regression coefficients in column (3) see Figure IV. (Robust) standard errors are reported in parentheses for columns (3) 1, 2.1 and 2.2. The stars on the coefficients are defined as follows: * $\left(^{* *}\right)$ and [***] refer to pvalues below $10 \%(5 \%)$ and $[1 \%]$. 
Table 5: Price Leadership (2)

\begin{tabular}{|c|c|c|c|c|c|c|}
\hline \multirow{3}{*}{ Dependent Variable } & \multirow{2}{*}{\multicolumn{2}{|c|}{$\begin{array}{cc}(1) & (2) \\
\text { Absolute \% Price } \\
\text { Difference To Leader }\end{array}$}} & \multicolumn{2}{|r|}{ (4) } & (5) & \multirow[t]{2}{*}{ (6) } \\
\hline & & & \multicolumn{3}{|c|}{$\%$ Price Difference To Leader } & \\
\hline & Coef. & S.E. & Coef. & S.E. & Coef. & S.E. \\
\hline Leader's price changes: & \multicolumn{2}{|c|}{ Pos \& Neg } & \multicolumn{2}{|c|}{ Positive } & \multicolumn{2}{|c|}{ Negative } \\
\hline $\begin{array}{l}\text { Policy Change } \\
\text { Policy*Leader changes } \\
\text { price dummy }\end{array}$ & $-0.00239 * * *$ & $(0.000290)$ & $-0.00464 * * *$ & $(0.000423)$ & $0.00178^{* * *}$ & $(0.000447)$ \\
\hline Lag 0 & $0.0459 * * *$ & $(0.000951)$ & $-0.0652 * * *$ & $(0.00167)$ & $0.0269 * * *$ & (0.00119) \\
\hline Lag 1 & $0.0194 * * *$ & $(0.000950)$ & $-0.0309 * * *$ & $(0.00167)$ & $0.00832^{* * *}$ & (0.00118) \\
\hline Lag 2 & $0.0138^{* * *}$ & $(0.000994)$ & $-0.0250^{* * *}$ & $(0.00167)$ & $0.00237 *$ & (0.00127) \\
\hline Lag 3 & $0.00409^{* * *}$ & $(0.000993)$ & $-0.00377 * *$ & (0.00191) & $0.00326^{* * *}$ & (0.00118) \\
\hline Lag 4 & -0.00109 & $(0.000993)$ & -0.00108 & $(0.00191)$ & $-0.00331 * * *$ & (0.00118) \\
\hline Lag 5 & $-0.00260^{* * *}$ & $(0.000994)$ & -0.00181 & $(0.00191)$ & $-0.00539 * * *$ & (0.00119) \\
\hline Lag 6 & $-0.00170 *$ & $(0.000995)$ & -0.00216 & (0.00191) & $-0.00536^{* * *}$ & (0.00118) \\
\hline $\begin{array}{l}\text { Leader changes price } \\
\text { dummy }\end{array}$ & & & & & & \\
\hline Lag 0 & $0.00197 * * *$ & $(0.000298)$ & $-0.00361 * * *$ & $(0.000425)$ & $0.00775^{* * *}$ & $(0.000464)$ \\
\hline Lag 1 & $0.000650^{* *}$ & $(0.000296)$ & $-0.00120 * * *$ & $(0.000424)$ & $0.00342^{* * *}$ & $(0.000457)$ \\
\hline Lag 2 & $4.87 e-05$ & $(0.000295)$ & -0.000518 & $(0.000424)$ & $0.00287^{* * *}$ & $(0.000459)$ \\
\hline Lag 3 & 0.000121 & $(0.000294)$ & 0.000435 & $(0.000421)$ & $0.00204^{* * *}$ & $(0.000459)$ \\
\hline Lag 4 & 0.000216 & $(0.000295)$ & 0.000147 & $(0.000421)$ & $0.00169 * * *$ & $(0.000465)$ \\
\hline Lag 5 & 0.000398 & $(0.000296)$ & $0.000879 * *$ & $(0.000421)$ & $0.00181 * * *$ & $(0.000463)$ \\
\hline Lag 6 & $0.000534 *$ & $(0.000298)$ & $0.00123^{* * *}$ & $(0.000430)$ & $0.00171 * * *$ & $(0.000452)$ \\
\hline Firms Fixed Effects & Yes & & Yes & & Yes & \\
\hline Constant & $0.00573^{* * *}$ & $(0.000157)$ & $0.00504 * * *$ & $(0.000247)$ & $0.00362 * * *$ & $(0.000221)$ \\
\hline Observations & 6,872 & & 3,960 & & 2,872 & \\
\hline R-squared & 0.338 & & 0.440 & & 0.376 & \\
\hline
\end{tabular}

Table 5 reports the estimation results of regression model (1) using a different dependent variable and OLS. It is an additional test to the results reported in Table 4 of whether ENI's competitors changed their pricing behaviour in response to the sticky pricing policy. The dependent variable in specification 1 is the absolute percentage price difference of competitor $j$ with respect to the leader in day $t$. In specifications 3 and 5 we consider only positive and negative price changes by the leader respectively. The dependent variable in these specifications is the percentage price difference with respect to the leader. Standard errors are reported in parentheses, the stars on the coefficients are defined as follows: $\left.{ }^{* *}\right)$ and $[* * *]$ refer to p-values below $10 \%(5 \%)$ and $[1 \%]$. 
Table 6: Dif-in-Dif Model

\begin{tabular}{|c|c|c|c|c|c|c|}
\hline \multirow{3}{*}{$\begin{array}{l}\text { Dependent Variable } \\
\text { Model: }\end{array}$} & (1) & (2) & (3) & (4) & (5) & (6) \\
\hline & \multicolumn{6}{|c|}{ Price of country $i$ ant time $t$} \\
\hline & $\mathrm{FE}$ & $\mathrm{FE}$ & $\mathrm{FE}$ & $\mathrm{FE}$ & $\mathrm{FE}$ & FE \\
\hline IT*Pol_Change & $\begin{array}{c}9.877 * * * \\
(1.970)\end{array}$ & $\begin{array}{c}9.863 * * * \\
(2.110)\end{array}$ & $\begin{array}{c}9.863 * * * \\
(2.126)\end{array}$ & $\begin{array}{c}9.877 * * * \\
(1.964)\end{array}$ & $\begin{array}{c}9.863 * * * \\
(2.101)\end{array}$ & $\begin{array}{c}9.863 * * * \\
(2.117)\end{array}$ \\
\hline Italy & & & & $\begin{array}{c}30.75^{* *} \\
(9.292)\end{array}$ & $\begin{array}{c}30.39 * * \\
(9.311)\end{array}$ & $\begin{array}{c}30.39 * * \\
(9.381)\end{array}$ \\
\hline Policy Change & $\begin{array}{c}0.245 \\
(3.196)\end{array}$ & $\begin{array}{c}-31.35^{* * *} \\
(3.634)\end{array}$ & $\begin{array}{c}-18.53 * * * \\
(2.778)\end{array}$ & $\begin{array}{c}0.245 \\
(3.185)\end{array}$ & $\begin{array}{c}-31.35^{* * *} \\
(3.619)\end{array}$ & $\begin{array}{c}-18.53 \text { *** } \\
(2.767)\end{array}$ \\
\hline Time Trend & $\begin{array}{c}0.706^{* * *} \\
(0.0340)\end{array}$ & $\begin{array}{c}0.152^{* * *} \\
(0.0396)\end{array}$ & $\begin{array}{c}0.475 \\
(0.284)\end{array}$ & $\begin{array}{c}0.706^{* * *} \\
(0.0339)\end{array}$ & $\begin{array}{c}0.152^{* * *} \\
(0.0394)\end{array}$ & $\begin{array}{l}0.475^{*} \\
(0.283)\end{array}$ \\
\hline Belgium & $\begin{array}{c}-37.98^{* * *} \\
(0.513)\end{array}$ & $\begin{array}{c}-37.84^{* * *} \\
(0.490)\end{array}$ & $\begin{array}{c}-37.84^{* * *} \\
(0.494)\end{array}$ & & & \\
\hline Germany & $\begin{array}{c}-53.68^{* * *} \\
(0.513)\end{array}$ & $\begin{array}{c}-52.78^{* * *} \\
(0.490)\end{array}$ & $\begin{array}{c}-52.78^{* * *} \\
(0.494)\end{array}$ & & & \\
\hline Spain & $\begin{array}{c}-28.29 * * * \\
(0.513)\end{array}$ & $\begin{array}{c}-27.78^{* * *} \\
(0.490)\end{array}$ & $\begin{array}{c}-27.78^{* * *} \\
(0.494)\end{array}$ & & & \\
\hline France & $\begin{array}{c}-77.39 * * * \\
(0.513)\end{array}$ & $\begin{array}{c}-77.90 * * * \\
(0.490)\end{array}$ & $\begin{array}{c}-77.90^{* * *} \\
(0.494)\end{array}$ & & & \\
\hline Greece & $\begin{array}{c}-4.272^{* * *} \\
(0.513)\end{array}$ & $\begin{array}{c}-4.656^{* * *} \\
(0.490)\end{array}$ & $\begin{array}{c}-4.656^{* * *} \\
(0.494)\end{array}$ & & & \\
\hline Netherlande & $\begin{array}{c}5.597 * * * \\
(0.513)\end{array}$ & $\begin{array}{c}4.751^{* * *} \\
(0.490)\end{array}$ & $\begin{array}{c}4.751 * * * \\
(0.494)\end{array}$ & & & \\
\hline Portugal & $\begin{array}{c}-32.33 * * * \\
(0.513)\end{array}$ & $\begin{array}{c}-29.94 * * * \\
(0.490)\end{array}$ & $\begin{array}{c}-29.94 * * * \\
(0.494)\end{array}$ & & & \\
\hline Austria & $\begin{array}{c}-17.69 * * * \\
(0.513)\end{array}$ & $\begin{array}{c}-17.01 * * * \\
(0.490)\end{array}$ & $\begin{array}{c}-17.01 * * * \\
(0.494)\end{array}$ & & & \\
\hline Brent (Lag 0-4) & & Y & $\mathrm{Y}$ & & $\mathrm{Y}$ & Y \\
\hline Year Fixed Effects & & & Y & & & Y \\
\hline Month Fixed Effects & & & Y & & & Y \\
\hline Constant & $\begin{array}{c}322.3 * * * \\
(1.568)\end{array}$ & $\begin{array}{c}139.2^{* * *} \\
(5.832)\end{array}$ & $\begin{array}{c}130.7 * * * \\
(5.304)\end{array}$ & $\begin{array}{c}291.6^{* * *} \\
(7.925)\end{array}$ & $\begin{array}{c}108.8^{* * *} \\
(11.51)\end{array}$ & $\begin{array}{c}100.3 * * * \\
(12.49)\end{array}$ \\
\hline Observations & 1,071 & 891 & 891 & 1,071 & 891 & 891 \\
\hline R-squared & 0.612 & 0.880 & 0.925 & 0.35 & 0.62 & 0.66 \\
\hline Number of Groups & 9 & 9 & 9 & 9 & 9 & 9 \\
\hline $\begin{array}{l}\text { Table } 6 \text { reports the estim } \\
\text { after the introduction of t } \\
\text { the coefficients on the b } \\
\text { specifications the coeffici } \\
\text { specifications show Italy's } \\
6 \text {, respectively. In all spec } \\
\text { clustered at country level } \\
\text { refer to o-values below } 10\end{array}$ & $\begin{array}{l}\text { alts of the di } \\
\text { pricing poli } \\
\text { \& countries } \\
\text { esent the ce } \\
\text { el compared } \\
\text { Italy's price } \\
\text { rentheses w }\end{array}$ & $\begin{array}{l}\text { n-dif regres } \\
\text { compared t } \\
\text { ile specifica } \\
\text { ttry specific } \\
\text { the benchr } \\
\text { innificantly }\end{array}$ & $\begin{array}{l}\text { model it } \\
\text { benchma } \\
4 \text { to } 6 \\
\text { ice differ } \\
\text {. Specific } \\
\text { eases afte }\end{array}$ & $\begin{array}{l}\text { It tests } \mathrm{v} \\
\text { U countri } \\
\text { rts Italy's } \\
\text { comparec } \\
1 \text { to } 3 \text { is } \\
\text { e policy w }\end{array}$ & $\begin{array}{l}\text { er Italian } \\
\text { pecificatio } \\
\text { d effect. I } \\
\text { Italy, whi } \\
\text { metric to s } \\
\text { troduced. }\end{array}$ & $\begin{array}{l}\text { ces increased } \\
1 \text { to } 3 \text { reports } \\
\text { he first three } \\
\text { the last three } \\
\text { cification } 4 \text { to } \\
\text { andard errors } \\
(* *) \text { and }[* * *]\end{array}$ \\
\hline
\end{tabular}


Table 7: Synthetic Control Method

\begin{tabular}{lc|cccccc}
\hline \multicolumn{2}{c}{$\begin{array}{c}\text { State weight to compute } \\
\text { "synthetic control group" }\end{array}$} & $\begin{array}{c}\text { Mean Italian } \\
\text { price }\end{array}$ & $\begin{array}{c}\text { Mean synthetic } \\
\text { control }\end{array}$ & Difference & t-statistic & p-value & Obs. \\
\hline Belgium & 0.021 & Entire Sample & & & & & \\
Germany & 0.014 & 368.85 & 366.51 & $2.33^{*}$ & 1.8 & 0.073 & 119 \\
Spain & 0.027 & Pre Sticky Pricing & & & & & \\
France & 0.004 & 354.85 & 354.82 & 0.02 & 0.02 & 0.981 & 88 \\
Greece & 0.058 & Sticky Pricing & & & & & \\
Netherlands & 0.814 & 408.60 & 399.72 & $8.88^{* *}$ & 2.6 & 0.014 & 31 \\
Portugal & 0.024 & & & & & & \\
Austria & 0.038 & & & & & & \\
\hline
\end{tabular}

The left part of Table 7 shows the weights that have been used to construct the synthetic control group. These weights are estimated by minimizing the difference between the pre-treatment (price policy change) Italian price and the other EU countries. The EU price which most closely resembles the Italian one is the Dutch price with a weight of .814. In the right part of the table we compare the Italian and synthetic control price in three different time periods: entire sample, pre and post treatment. By construction the weights are chosen to maximize the similarity of the Italian and synthetic price before the treatment, and thus their difference is small and insignificant. This guarantees that the synthetic control group more closely resembles Italian price movements before the policy and allows us to estimate the causal effect of ENI's new pricing policy on prices. "Difference" shows the difference between Italian and synthetic price, while t-statistic and p-value report the estimates of the test: $\mathrm{H}_{0}$ : IT_PriceSynth $=0$. The estimated price difference in the sticky pricing period is $8.88 €$ per 1000 liters which is statistically significant at the $5 \%$ level.

Table 8: Synthetic Control Regressions

\begin{tabular}{cccc}
\hline \multirow{2}{*}{$\begin{array}{l}\text { Dependent variable } \\
\text { Model }\end{array}$} & \multicolumn{2}{c}{$(1)$} & \multicolumn{2}{c}{$(2)$} & $(3)$ \\
& IT-Synthetic Control price & at time $t$ \\
Policy Change & $8.856^{* * *}$ & OLS & OLS \\
\hline Time Trend & $(3.59)$ & $(3.059)$ & $12.551^{* * *}$ \\
& & & $(4.224)$ \\
Brent (Lag Dif 0-4) & & .048 \\
Constant & .028 & .561 & $(.0369)$ \\
& $(1.197)$ & $(1.064)$ & Yes \\
& & & $(1.752)$ \\
Observations & 119 & 94 & 94 \\
R-squared & .076 & .479 & .486 \\
\hline
\end{tabular}

In Table 8 we run an OLS regression of the policy change dummy, policy, on the price difference between Italy and the Synthetic Control, $\triangle$ Price $I T-S y n t, t, \mathrm{t}$ In specifications 2 and 3 we add the lagged first differences of the Brent. Results are consistent with the dif-in-dif model and show a significant positive change in the Italian price difference with respect to the synthetic control after the policy. Robust standard errors are in parentheses. ${ }^{*}(* *)$ and $[* * *]$ refer to $p$-values below $10 \%(5 \%)$ and $[1 \%]$. 
Table 9: Robustness check

\begin{tabular}{|c|c|c|c|c|c|c|}
\hline \multirow{3}{*}{ Dependent Variable } & \multicolumn{4}{|c|}{ (2) } & \multicolumn{2}{|l|}{ (3) } \\
\hline & \multicolumn{6}{|c|}{ Margin of firm $i$ at time $t$} \\
\hline & Coef. & St. Err & Coef. & St. Err & Coef. & St. Err \\
\hline Time period & \multicolumn{2}{|c|}{ Pre Sticky Pricing } & \multicolumn{2}{|c|}{ Sticky Pricing } & \multicolumn{2}{|c|}{ All } \\
\hline Policy Change & & & & & $22.95^{* * *}$ & $(2.036)$ \\
\hline API & $2.692 * * *$ & $(0.836)$ & -2.070 & $(2.844)$ & $2.692 * * *$ & $(0.836)$ \\
\hline ERG & 1.372 & (0.838) & -1.674 & $(2.847)$ & 1.372 & $(0.839)$ \\
\hline ESSO & $1.460^{*}$ & $(0.848)$ & -1.281 & $(2.887)$ & $1.460^{*}$ & $(0.848)$ \\
\hline IP & $1.840^{* *}$ & $(0.854)$ & -0.635 & $(2.891)$ & $1.840^{* *}$ & $(0.854)$ \\
\hline Q8 & $2.273 * * *$ & $(0.831)$ & -0.938 & $(2.905)$ & $2.273 * * *$ & $(0.832)$ \\
\hline SHELL & $1.633^{*}$ & (0.858) & -1.682 & $(2.880)$ & $1.633^{*}$ & $(0.858)$ \\
\hline TAMOIL & $1.843^{* *}$ & $(0.849)$ & -2.437 & $(2.829)$ & $1.843^{* *}$ & $(0.850)$ \\
\hline TOTAL & $2.692 * * *$ & $(0.843)$ & -1.270 & $(2.848)$ & $2.692 * * *$ & $(0.843)$ \\
\hline Policy*API & & & & & -2.070 & $(2.827)$ \\
\hline Policy*ERG & & & & & -1.674 & (2.831) \\
\hline Policy*ESSO & & & & & -1.281 & $(2.870)$ \\
\hline Policy*IP & & & & & -0.635 & $(2.872)$ \\
\hline Policy*Q8 & & & & & -0.938 & $(2.887)$ \\
\hline Policy*SHELL & & & & & -1.682 & $(2.864)$ \\
\hline Policy*TAMOIL & & & & & -2.437 & $(2.814)$ \\
\hline Policy*TOTAL & & & & & -1.270 & $(2.830)$ \\
\hline Time Trend & $-0.0144 * * *$ & (0.00103) & $-0.0896^{* * *}$ & $(0.0115)$ & $-0.0159 * * *$ & $(0.00104)$ \\
\hline Constant & $374.6^{* * *}$ & $(16.51)$ & $1,637 * * *$ & $(190.2)$ & $398.3^{* * *}$ & $(16.68)$ \\
\hline Observations & 6,129 & & 1,665 & & 7,794 & \\
\hline R-squared & 0.034 & & 0.033 & & 0.115 & \\
\hline
\end{tabular}

Table 9 reports the estimates of regression model (5). The dependent variable, margin, is expressed in Euro per 1000 liters. In specification 1 (2) we include only firm fixed effect for the pre (post) policy period. In specification (3) we include both the pre and post sticky pricing time period, firm fixed effects and their interaction with the policy dummy. The results show that while competitors' margins were significantly higher than ENI's margins before the policy, after the policy this difference becomes insignificant. In addition, the estimate on the policy dummy which captures the post policy difference in average industry margins is positive and significant. This shows that controlling for firms' fixed effects the policy had a positive impact on the profitability of the Italian gasoline industry. Robust standard errors are in parentheses while the stars on the coefficients are defined as follows: * (**) and [***] refer to p-values below 10\% $(5 \%)$ and $[1 \%]$. 
Figure I: Cartel Formation

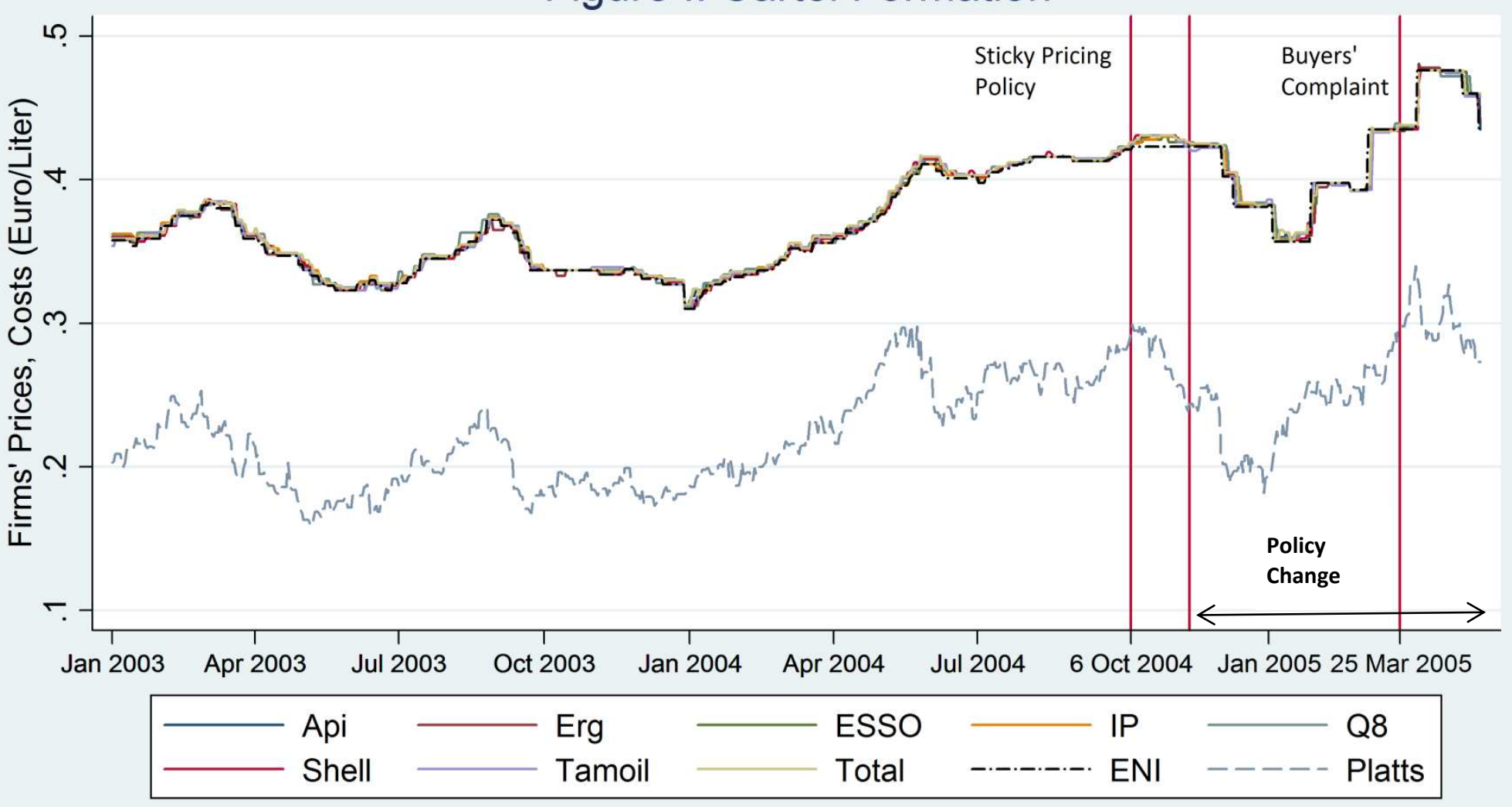

Figure I shows the daily "suggested" firm-level prices in the Italian gasoline market from January 2003 to $15^{\text {th }}$ May 2005. These prices represent a very good approximation of final retail prices paid by consumers, see section 3.2. The dashed line represents the Platts Cif Med, the major source of cost for firms. The first vertical line denotes $6^{\text {th }}$ October 2004, the date where ENI, the market leader, announced that it would adopt a new pricing policy consisting of sticky prices (i.e. infrequent price changes). The time span between the first two vertical lines constitutes the "commitment" time period. As prices respond to costs with about a month time lag costs were increasing just after the announcement by ENI contrary to what might seem from Figure I. Competitors kept increasing their prices following short-run cost changes until the beginning of November when costs decreased and they started to align and follow the leader's price. The second vertical line is placed on the $12^{\text {th }}$ of November, the date when most competitors aligned to the leader. Note that we will take this date as the starting date of the new equilibrium in the empirical analysis. The third vertical line shows the date when the Italian Truckers' Association (FITA) formally complained about "high and aligned prices" to the Italian antitrust authority. 
Figure II: Italian Price, EU Price and Brent

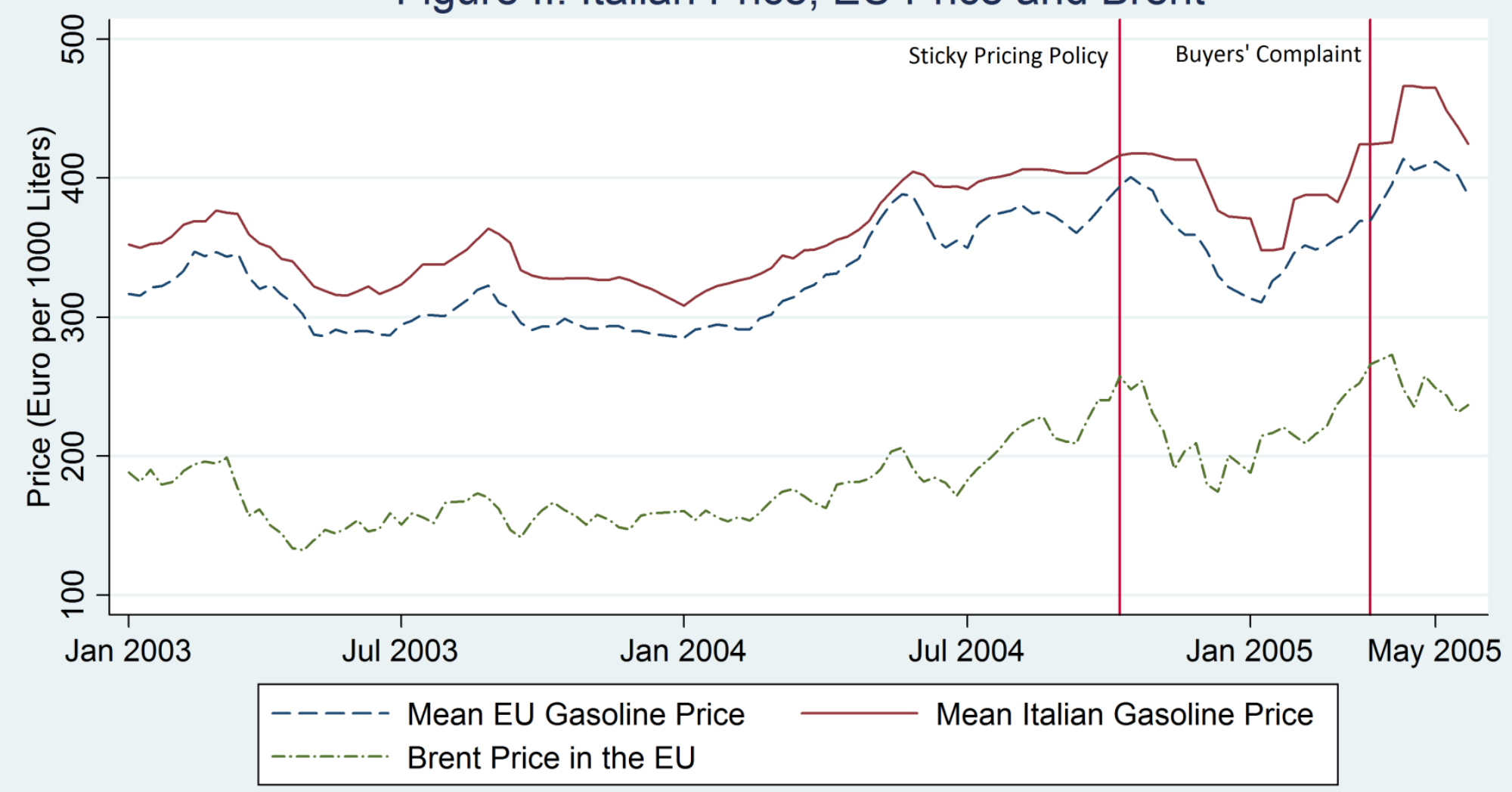

Figure II shows the average weekly Italian and EU price of gasoline and the European price of the Brent, i.e. crude oil. The continuous line represents the Italian price, while the dashed (dashed-dotted) line represents the EU price (Brent). The first vertical line denotes the date where the market leader announced that it would adopt a new pricing policy consisting of sticky pricing (i.e. infrequent price changes). The second vertical line shows the date when the Italian Truckers' Association (FITA) formally complained about "high and aligned prices" to the Italian Antitrust Authority on 25 $5^{\text {th }}$ March 2005. 
Figure III: Alignment and Price Dispersion
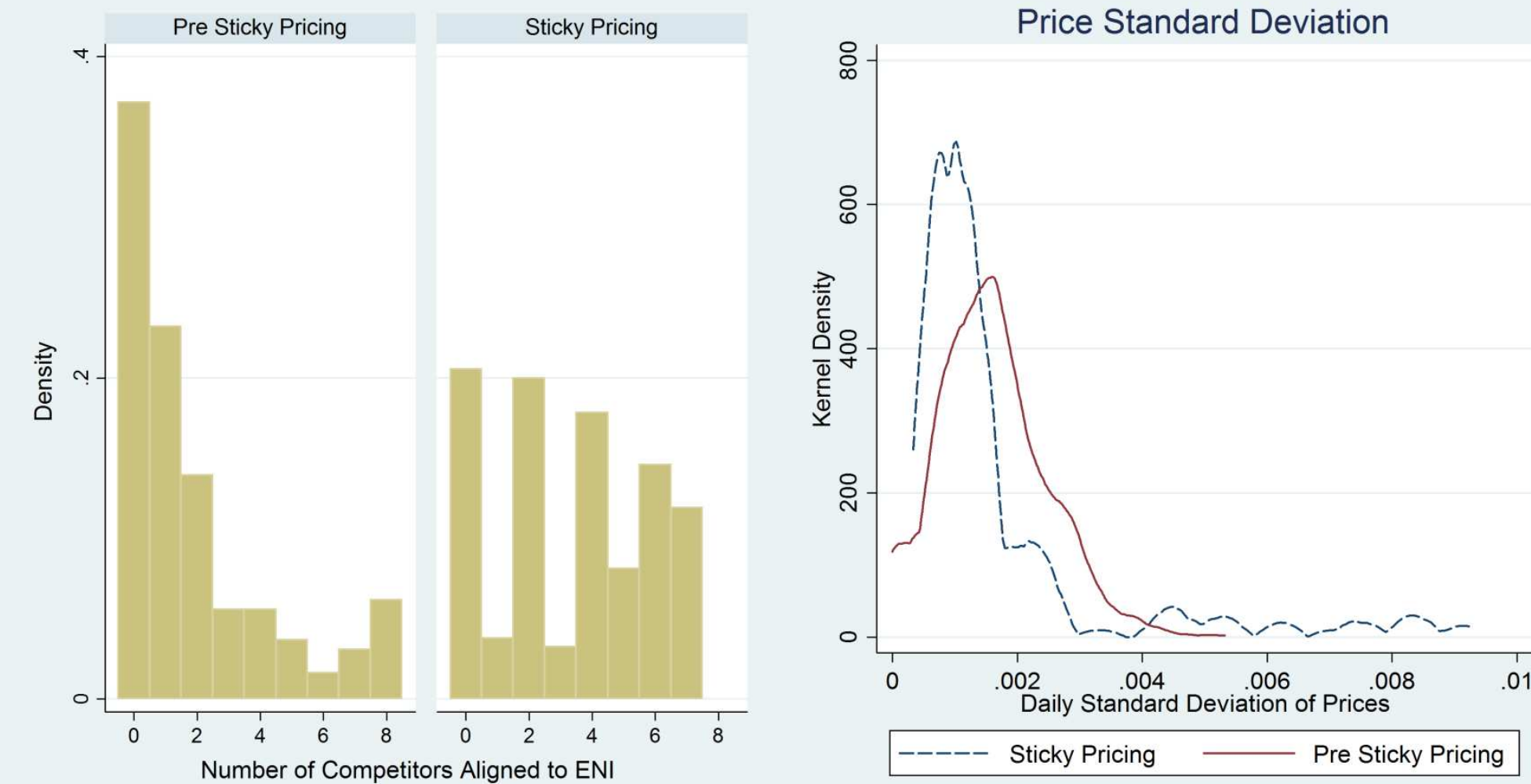

Figure III shows the distribution of the number of firms aligned to the leader (left graph) and the kernel density of the daily standard deviation of prices (right graph) both for the sticky and pre sticky time period. Alignment is a count variable that ranges from 0 (none of ENI's competitors charge exactly the same price as ENI) to 8 (all competitors are aligned). The right part of Figure III shows the kernel density of the daily price dispersion across firms. As ENI increased the magnitude and time interval of price changes the mean (median) price dispersion increased (decreased) during the sticky pricing period. 


\section{Figure IV: Dynamic Price Alignment to the Leader}

Pre Sticky Pricing

Sticky Pricing

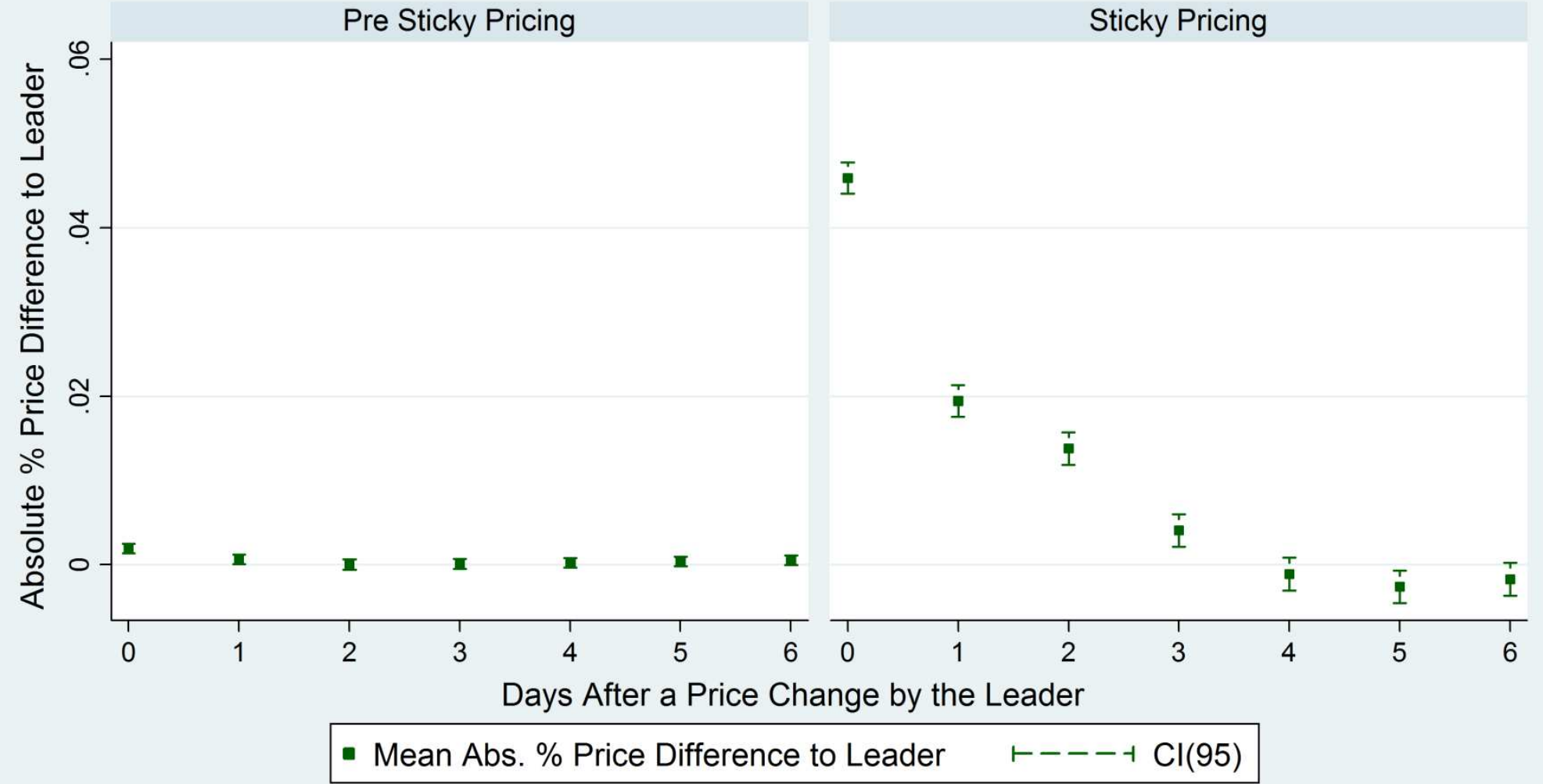

Figure IV shows the coefficients of specification 3 in regression model (1), reported in Table 3 . The coefficients describe the dynamic alignment of competitors after a price change by the leader both before the new policy (left graph) and after the new policy (right graph). Before the policy the average absolute percentage price difference to the leader did not significantly change in response to a price change by the leader. In contrast, after the policy change competitors significantly changed their pricing behaviour. They dynamically aligned their prices to the leader's price with two to three days lag after a price change by the leader. The absolute price difference is $4.5 \%$ on days where the leader changed its price and then quickly drops until it gets insignificant after the fourth day. 
Figure V: Italian Price and Synthetitc Control
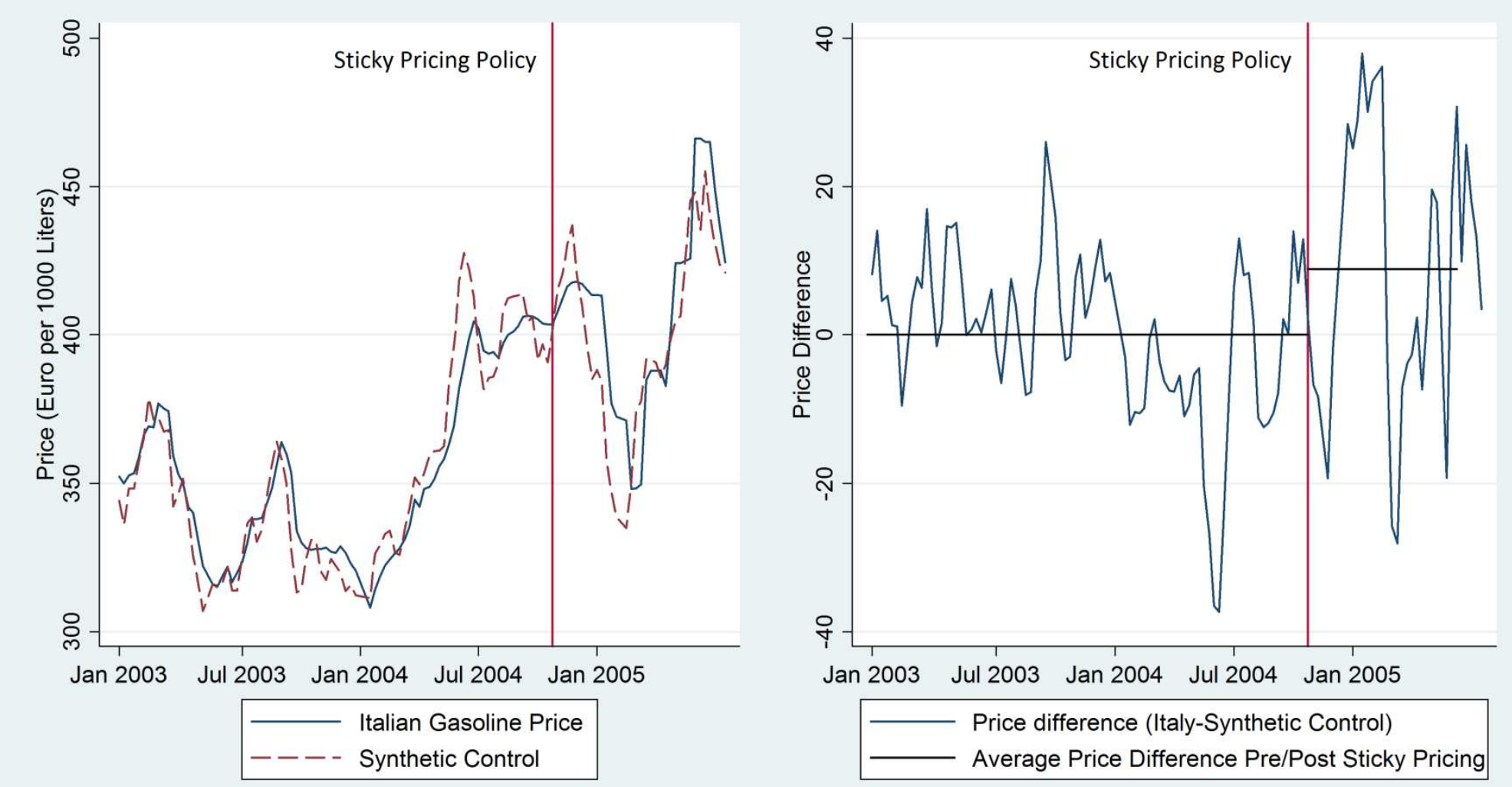

Figure V shows the mean Italian gasoline price and the synthetic control group on the left graph and their difference on the right graph. The weights to construct the synthetic control group are reported in Table 5. The vertical lines in both graphs denote the date where ENI announced that it would adopt a new pricing policy consisting of sticky prices (i.e. infrequent price changes). 